\title{
EESTI ÜLEVÕTMINE SAKSA OKUPATSIOONIVÕIMUDELT NOVEMBRIS 1918
}

\author{
Ago Pajur
}

Eesti iseseisvuse sünniloos kerkib esile kolm daatumit, mida võib tinglikult pidada Eesti vabariigi sünnipäevaks: 15. (ukj 28.) november 1917, mil maanõukogu kuulutas end ainsaks kõrgeima võimu kandjaks Eestis, lahutades seeläbi Eesti Venemaast; 24. veebruar 1918, mil rahvusmeelsed jõud võtsid enamlastelt võimu Tallinnas ja moodustasid Eesti ajutise valitsuse; 11. november 1918, mil Saksa okupatsiooni ajal tegevuse katkestanud ajutine valitsus taas kokku tuli ning alustas omariikluse tegelikku ülesehitamist.

Kui kahest esimesest daatumist ning neile eelnenud ja järgnenud sündmustest on suhteliselt rohkesti kirjutatud ${ }^{1}$, siis 11 . november 1918 pole samasugust tähelepanu pälvinud. Muidugi ei saa öelda, nagu poleks toonaseid olusid üldse uuritud. Vastupidi, omariikluse loomist on kirjeldatud pea kõigis Eesti ajaloo üldkäsitlustes ning põhjalikult analüüsitud mitmes monograafias. ${ }^{2}$ Lisaks on sellega seotud üksikküsimusi vaadeldud mujalgi ${ }^{3}$ ja leidub ka mälestusi kaasaegsetelt ${ }^{4}$. Sellele vaatamata võib väita, et 1918. aasta november alles ootab uurijaid.

Senise suhteliselt tagasihoidliku tähelepanu üheks põhjuseks on allikmaterjalide nappus, kuna riigiloojad keskendusid omariikluse aluste rajamisele, mitte aga toimuva dokumenteerimisele ja dokumentide säilitamisele. Seetõttu tuleb ajaloolastel suures osas tugineda sekundaarsetele allikatele, nagu ajakirjandus ja mälestused, mille usaldusväärsus jätab aga paratamatult soovida.

\footnotetext{
1 Nt: Vabaduse tulekul I: koguteos Eesti Maanõukogu 1917. aasta 15./28. nov. otsuse tähistamiseks (Tartu: Akadeemia, 1938); Iseseisvusmanifest: artikleid, dokumente ja mälestusi (Tartu: Rahvusarhiiv, 2014).

2 Nt: Eduard Laaman, Eesti iseseisvuse sünd (Tartu: Loodus, 1936); Mati Graf, Eesti rahvusriik: ideed ja lahendused: ärkamisajast Eesti Vabariigi sünnini (Tallinn, 1993).

3 Nt riigikaitse loomisest: Eesti Vabadussõda 1918-1920, I-II (Tallinn: Vabadussõja Ajaloo Komitee, 1937/39).

4 Nt Mälestused iseseisvuse võitluspäivilt, I-II (Tallinn: Eesti Ajakirjanikkude Liit, 1927/1929).
} 
Kuna riikluse ülesehitamise protsess oli keerukas ja paljuharuline, siis pole mõeldav selle käsitlemine ühes artiklis, mistap keskendutakse järgnevalt üksnes ühele aspektile - võimu ülevõtmisele Saksamaa haldusametnikelt.

\section{Taust ja eellood}

Ilmasõja viimase aasta (1918) kevad ja suvi näisid soosivat keiserlikku Saksamaad. Pärast Brest-Litovski rahulepingu sõlmimist likvideerus senine idarinne ja hulk väekoondisi paisati läände. Kuid loodetud strateegilist edu, ammugi mitte otsustavat pööret sõjas, ei saavutatud. Saksamaa olukorda halvendas Ameerika Ühendriikide sekkumine sõtta. Ookeani tagant saabus Euroopasse hulgaliselt moodsat sõjavarustust ning miljoneid sõdureid, kes ei kannatanud kurnatuse ja sõjatüdimuse all. Tänu sellele panid lääneliitlased oma ülekaalu maksma, sundides sakslasi taanduma Hindenburgi liinile. 27. septembril murdsid vastased sellestki läbi. ${ }^{5}$

Saksamaa eliit asus otsima võimalusi sõja lõpetamiseks. 3. oktoobril riigikantsleriks nimetatud Badeni prints Maximilian tegi Entente' ile ettepaneku alustada kõnelusi vaherahu sõlmimiseks. Kuid see samm osutus ebapiisavaks. Sõjaliste nurjumistega kaasnes riigis rahulolematuse ja revolutsioonilisuse kasv. 29. oktoobril puhkes Saksamaa peamises sõjasadamas, Wilhelmshavenis madruste vastuhakk, mis kasvas loetud päevadega üleriigiliseks Novembrirevolutsiooniks. Keiser Wilhelm II lahkus troonilt, prints Maximilian andis valitsusohjad üle Friedrich Ebertile, Saksamaa kuulutati vabariigiks ja 11. novembril kirjutati Compiègne'i metsas alla relvarahule, mis lõpetas ilmasõja. ${ }^{6}$

Compiègne'i relvarahu nõudis muuhulgas Brest-Litovski lepingu tühistamist ja Saksa vägede lahkumist sõja eel Venemaale kuulunud aladelt.7 See tähendas, et Eesti mandriosas ligi 9 ja Lääne-Eesti saartel koguni 13 kuud võimutsenud Saksa administratsioon saab otsa. Eesti rahvuslike jõudude ees näis avanevat võimalus naasta omariikluse loomise juurde.

Lihtsaks ei tõotanud see aga kujuneda. Saksa võimud olid teinud lõpu poliitilisele tegevusele, keelustanud rahvakogunemised, likvideerinud

\footnotetext{
5 John Keegan, Esimene maailmasõda (Tallinn: Varrak, 2002), 380-399.

6 Vt Reinhard Sturm, "Vom Kaiserreich zur Republik 1918/19", Informationen zur Politischen Bildung 2011, Nr 261 (http://www.bpb.de/izpb/5549/vom-kaiserreich-zurrepublik-1918-19? $\mathrm{p}=$ all, vaadatud 11.08 .2018 )

7 "Compiegne'i vaherahuleping Saksamaa kohustustest Ida-Euroopas, 11.11.18", Kodusõda ja välisriikide interventsioon Eestis 1918-1920: dokumente ja materjale, I (Tallinn: Eesti Raamat, 1984), 97.
} 
erakonnad, asendanud ajakirjandusvabaduse tsensuuriga, arreteerinud juhtivaid iseseisvuslasi. Eesti vabariigist ei tahetud kuuldagi, maanõukogul ei lastud koguneda, ajutise valitsuse kooskäimisi salliti vaid märtsi keskpaigani ning rahvusväeosade tegevust aktsepteeriti üksnes Põhja-Eestis ja sealgi lühiajaliselt.

Kogu võim kuulus Saksa sõjaväelastele: okupeeritud idaaladel - Saksa relvajõudude ülemjuhatusele idas (Ober-Ost; kindralfeldmarssal Baieri prints Leopold); endistes Balti kubermangudes - 8. armee ülemjuhatusele (A.O.K.8; jalaväekindral Hugo von Kathen); Lõuna-Eestis - 60. armeekorpuse juhatusele (Generalkommando 6o; kindralleitnant Ludwig von Estorff); Põhja-Eestis - 68. armeekorpuse juhatusele (Generalkommando 68 ; kindralleitnant Adolf von Seckendorff); Lääne-Eesti saartel - Saaremaa sõjakubernerile (kindralleitnant William Balck); maakondades ja suuremates linnades - Saksa ohvitseridest maakonna- või linnapealikutele (Kreishauptmann, Stadthauptmann). Sõjaväelaste jaoks võõrastes oludes orienteerumiseks moodustati mitmeid nõukodasid (Beirat), kus andsid tooni baltisakslased, ehkki kaasati ka kadakasaksu. 1917. aastal demokraatlike üldvalimiste läbi moodustatud kohalikud omavalitsused saadeti laiali ja nende volikogud asendati sõjaväe päevakäskude alusel ametisse määratud üksikisikutega: linnapeadeks (Bürgermeister) ja kihelkondade eestseisjateks (Amtsvorsteher) nimetati baltisakslasi, valdade eestseisjateks (Ortsvorsteher) aga eestlasi.

Pärast seda, kui Venemaa loobus 27. augustil vormilisest suveräniteedist Eesti- ja Liivimaa üle, hakati sõjaväelise haldusaparaadi kõrvale kujundama tsiviiladministratsiooni. Kutsuti ellu Baltimaade sõjaväeline valitsus (Militärverwaltung im Baltenland), mille eesotsas seisis riigipäevasaadik Alfred von Gossler. Nii Gossler kui talle allunud Eestimaa, Liivimaa ja Kuramaa provintsivalitsused (Provinzialverwaltung) said korraldusi osalt 8. armee ülemjuhatuselt, osalt aga Saksamaa siseministeeriumilt. Provintsivalitsus koordineeris maakonna- ja linnapealike tegevust, kindralkomando aga keskendus militaarküsimustele. ${ }^{8}$

Siiski ei õnnestunud sakslastel Eesti iseseisvusliikumist täielikult tasalülitada. Vabadusse jäänud ajutise valitsuse liikmed pidasid salaja sidet nii omavahel kui ka välisdelegatsiooniga. Mitmed avaliku elu tegelased kohtusid Eestit väisanud kõrgete Saksa sõjaväelaste ja poliitikutega (kindraladmiral Preisi prints Heinrich, kindralfeldmarssal Baieri prints Leopold, ratsaväekindral Mecklenburgi hertsog Paul Friedrich, välisministeeriumi riigisekretär Max Wallraf, riigivarade ministeeriumi riigisekretär krahv

8 Tallinna ajalugu III: Vene linnaseaduse kehtestamisest (1877) nü̈̈disajani [ilmumisel]. 
Siegfried von Roedern jt), üritades tutvustada Eesti olusid ja esitada koguni mõningaid sooviavaldusi.

Alates oktoobrist täheldati survepoliitika mõningast nõrgenemist. Olukorda kasutades nõutas Jaan Poska kindral Seckendorffilt välja loa Eesti erakondade juhatustele koosolekute pidamiseks (kuna koosolekud pidanuks toimuma Saksa usaldusmeeste kontrolli all, siis eestlased loobusid võimalusest). 21. oktoobril vabastati vangistusest päästekomitee liige Konstantin Konik ja maanõukogu esimees Otto Strandman. Mitmed Saksa poliitikud otsisid kontakte eestlastega ning mõned neist vihjanud koguni, et Saksa võim Eestis pole igavene. ${ }^{9}$

Riigipäeva saadik Gerhart von Schulze-Gaevernitz kinnitas 23. oktoobril toimunud kohtumisel eestlastega, et: esiteks, poliitiliselt ei suuda Saksamaa Baltimaid toetada, kuid Saksa väed jätkavad nende sõjalist kaitset kuni rahulepingu sõlmimiseni; teiseks, senine sõjaväeline administratsioon asendatakse tsiviilvalitsusega, mille kõrgeimaks halduriks saab Baltimaade riigikomissar, kes hakkab alluma mitte Saksamaa sise-, vaid välisministeeriumile; kolmandaks, Saksamaa on eluliselt huvitatud baltisakslaste koostööst põlisrahvastega. Eestlased vastasid märgukirjaga, kinnitades, et rahvuslike erakondade püüdeks on sõltumatu Eesti vabariik, mistõttu on hädavajalik likvideerida võimalikult kiiresti Saksa sõjaväevalitsus ja kutsuda kokku Eesti maanõukogu, kes korraldab asutava kogu valimised. Rahvusvähemustele (eeskätt baltisakslastele) lubati tagada proportsionaalne valimisõigus ja kooliautonoomia. Dokumendile kirjutasid alla Jaan Poska (Eesti demokraatlik erakond), Jüri Jaakson (Eesti radikaaldemokraatlik erakond), Nikolai Köstner (Eesti sotsiaaldemokraatlik tööliste partei) ning Otto Strandman ja Konstantin Konik (Eesti tööerakond). Märgukiri valmistas Schulze-Gaevernitzile pettumuse, kuna tema lootused eestlaste ja baltisakslaste koostööle kukkusid läbi. Siiski lubas ta aidata kaasa poliitilistel põhjustel vahistatud eestlaste vabastamisele. ${ }^{10}$

Väärib tähelepanu, et kui eestlaste kõnelused Schulzega said teatavaks, nõudis baltisaksa ajakirjandus osalejate andmist kohtu alla, kuid Saksa politsei piirdus vaid nende küsitlemisega. Eduard Laamani sõnul sai selgeks, et sakslastel on eestlaste suhtes kolm erinevat seisukohta: üks Saksamaa uuel valitsusel, teine sõjaväevõimudel ja kolmas siinsetel baltisakslastel. ${ }^{11}$

9 Eduard Laaman, Eesti iseseisvuse sünd ([2. trükk] Stockholm: Vaba Eesti, 1964), 329 (edaspidi viidatud Laamani teose seda trükki).

10 Ibid., 330-331; Eduard von Dellingshausen, Kodumaa teenistuses: Eestimaa Rüütelkonna peamehe mälestused (Tallinn: Olion, 1994), 202-203; "Läbirääkimised Tallinnas", Tallinna Teataja, nr 63, 11.11.1918.

11 Laaman, Eesti iseseisvuse sünd, 331. 
Mõistagi olid just viimased, unistades ühendatud Balti hertsogiriigist (Vereinigtes Baltisches Herzogtum), kõige tulisemalt eestlaste ja lätlaste rahvuslike taotluste vastu.

Aktiviseerus ka ajutine valitsus. Oktoobri lõpus teatati välisdelegatsioonile, et: "Sampo [valitsus] jääb siia, ainult tema üksikud chefid - vizedirektor S. [välisminister Otto Strandman] ja finantschef [rahaminister Juhan Kukk] delegeeritakse lähemail päevadel võõrsile."12 3. novembril valminud dokument volitas välisminister Strandmani, rahaminister Kukke, sõjaminister Andres Larkat, põllutööminister Jaan Raamotit, portfellita ministrit Jaan Tõnissoni ning välisdelegatsiooni liikmeid sõlmima lepinguid välisriikidega. ${ }^{13}$ Ulatuslikum "ministrite väljalend” jäi küll ära, kuid välisminister Strandman jõudis 6. novembril tõepoolest Helsingisse. Lisaks oli sõjaminister Larka 22. oktoobril kohtunud Kopenhaagenis välisdelegatsiooni nn Skandinaavia keskusega. ${ }^{14}$

\section{Tallinn muutub rahutuks}

Vaatamata üksikutele märkidele, mis lubasid loota muutusi, jäi okupatsioonivõimude tegevus endiseks - jätkus nii poliitiline surve kui ka materiaalsete vahendite, eriti toiduainete väljavedu Eestist. Just viimane sai järgnenud sündmuste ajendiks. Novembri alguspäevil toimus sakslaste juhitud Eestimaa varustustsentraalis (toitlusametis) suurem nõupidamine, kus kurdeti, et maarahvas täitvat oma kohustusi normivilja loovutamisel väga visalt, mistõttu jätkuvat Tallinnas leivavilja vaid paariks päevaks. ${ }^{15} 5$. novembril teatas Tallinna Päevaleht, et alates järgmisest päevast alandatakse elanike igapäevast leivanormi $1 / 2$ naelalt ${ }^{16} 3 / 8$ naelani. Kompensatsiooniks lubati suurendada kartulinormi, kuid see ei korvanud kärpimist. ${ }^{17}$

Kui ametlike selgituste kohaselt olid toiduvarude nappuses süüdi eesti talumehed, kes ei täitvat rekvisitsioonikohustust, siis rahvas pidas põhjuseks toiduainete väljavedu Saksamaale. Tänini ei ole selge, kui ulatuslik see väljavedu tegelikult oli. Kindlasti kasutati siinseid põllu- ja karjasaadusi Eestis paiknenud Saksa sõjameeste toitmiseks ning kindlasti leidus

\footnotetext{
12 Rahvusarhiiv [edaspidi RA], ERA.31.1.19o, 1. 2: Ajutise valitsuse juhised välisdelegatsioonile, okt. 1918.

13 RA, ERA.31.1.19o, 1. 17-20: Ajutise valitsuse volitused, 03.11.1918.

14 Ants Piip, Tormine aasta: ülevaade Eesti välispoliitika esiajast 1917-1918. aastal dokumentides ja mälestusis ([2. trükk] Stockholm: Vaba Eesti, 1966), 337.

15 “Toitluserahutused Tallinnas", Tallinna Teataja, nr 63, 11.11.1918.

161 nael $=409,5$ grammi.

17 “Teadaandmine”, Tallinna Päevaleht, nr 118, 05.11.1918.
} 
hulgaliselt Saksa sõjaväelasi, kes saatsid omaalgatuslikult toidupakke nälgivatele omastele kodumaal. Kuid mingi osa varutud toiduainetest veeti Eestist välja ka sõjaväevõimude otsesel korraldusel. Välisdelegatsioonini jõudnud informatsioonis väideti, et 5 . novembril seisis Tallinna reidil 22 Saksa transpordilaeva, kuhu laaditi suures koguses Eestimaa varasid, sh võid ja mune. ${ }^{18}$

Igatahes tegi leivanormi kärpimine tallinlased, eriti normitoidust enim sõltunud vaesemad kihid, kurjaks. 7. novembril kogunes hulk töölisnaisi toitlusameti juurde, protesteerides leivanormi vähendamise ja vilja väljaveo vastu. Järgmisel päeval rahulolematus laienes. Mitmed vabrikud (Dvigatel, Krull, Luther, Mayer, Noblessner, Balti manufaktuur, sadamatehas, tselluloosivabrik) pandi seisma ja töölised valgusid tänavatele. Toimusid rongkäigud ja miitingud, lauldi Marseljeesi, peeti kõnesid, milles arvustati toitlusametit ja nõuti selle likvideerimist. Levitati lendlehti, kus kutsuti nälgivaid töölisi üles ründama toitlusametit, mis veab röövitud toiduaineid maalt välja. Mõnel pool ajasid sõjaväepatrullid rahva laiali, kuid tõsisema vägivalla rakendamisest hoiduti ning miitinguliste esindajad pääsesid nii linnapealiku kui ka kindralkomando staabiülema jutule. Meelte rahustamiseks andis linnapealik Schmidt loa valida igast tehasest paar tööliste esindajat, kes saaksid võimaluse kontrollida linnavalitsuse ja linna toitlusameti tegevust või ehk koguni osaleksid edaspidi nende töös.

Sellest järeleandmisest said innustust sotsiaaldemokraadid. Nende aktivistid (Karl Ast, Aleksander Oinas, Otto Sternbeck, Aleksander Tulp jt) kogunesid 8. novembri õhtul suurärimeeste Puhkide majja ning otsustasid kasvatada stiihilised rahutused sihiteadlikuks poliitiliseks väljaastumiseks. Koostati üleskutse, milles nõuti toiduainete väljaveo lõpetamist, Saksa vägede lahkumist ja võimu üleandmist demokraatlikult valitud omavalitsusasutustele. Öö jooksul üleskutse paljundati ja hommikul levitati seda kui Eesti Sotsiaaldemokraatliku Tööliste Partei Tallinna komitee lendlehte. ${ }^{19}$

9. novembril kirjutati kindralkomando päevaraamatus: "Näljamässuga alanud rahutused omandavad poliitilise iseloomu ja tõsisema kuju."20 Hommikul kogunesid töölisesindajad Valvaja seltsimajja. Teavitati üksteist

18 RA, ERA.31.1.19o, 1. 7: Välisdelegatsiooni ülevaade sündmustest kodumaal, nov. 1918.

19 Laaman, Eesti iseseisvuse sünd, 345; "Kui Seckendorff üle võeti ja Dellingshausen teda manitsema lendas", Vaba Maa, nr 268, 14.11.1931, 6; "Suurearvulised meeleavaldused Tallinnas", Tallinna Päevaleht, $\mathrm{nr}$ 122, 11.11.1918; “Toitluserahutused Tallinnas; RA, ERA.2124.3.1727, pag-mata: Väljavõtted kindralkomando 68 sõjapäevaraamatust, 08.11.1918.

20 RA, ERA.2124.3.1727, pag-mata: Väljavõtted kindralkomando 68 sõjapäevaraamatust, 09.11.1918. 
erinevates tehastes valitsevast olukorrast ja meeleoludest ning kaaluti edasisi tegevusvõimalusi. Üksmeelselt otsustati, et koostööle Saksa linnavalitsuse ja toitlusametiga ei minda, vaid piirdutakse nende tegevuse üle revisjoni korraldamisega. Sotsiaaldemokraatide lendlehte aluseks võttes koostati kirjalik pöördumine, mis sisaldas lisaks toitlusolukorra parandamise soovile ka poliitilisi nõudmisi. Õigupoolest olid viimased selges ülekaalus. Muuhulgas nõuti Saksa vägede lahkumist, võimu loovutamist Eesti asutustele (maanõukogu ning maakondade, linnade ja valdade esinduskogud), kodanikuõiguste taastamist, poliitiliste vangide vabastamist, Balti maanõukogu ${ }^{21}$ laialisaatmist, 8-tunnise tööpäeva sisseseadmist ning loomulikult ka toiduainete väljaveo keelustamist. Ühtlasi sedastati: “[...] praeguse aja viletsused, muu seas tööpuudus ja nälg, kõik ühestainsast hallikast pärit on, nimelt sellest õigluseta seisukorrast, millesse okkupatsionivõim meie maa on seadnud."22 Lisaks kirjalikus pöördumises sisaldunud nõudmistele kavatseti esitada teisigi tööliskoosolekutel esile kerkinud soove, nagu palgatõus, tööliste vabastamine tulumaksust, liigkasuvõtjate tegevuse peatamine ning uute toidunormide (igapäevaselt 1,5 naela leiba ja 1,5 naela kartuleid, iganädalaselt 1 nael võid või rasva, igakuiselt 3 naela tangu ja 2 naela peenjahu), samuti soola, petrooleumi ja küttepuude normide kehtestamine. Koosolekul moodustati kaks esindust, millest üks läkitati Tallinna linnavalitsusse ja teine Eestimaa toitlusametisse (varustustsentraal).

Otto Sternbecki juhitud delegatsioon kohtus raekojas linnapealik Schmidtiga, kes võttis eestlased heatahtlikult vastu. Alustuseks tegi ta küll näo, nagu oleks eelmisel päeval antud lubaduse unustanud, kuid kui talle seda "meelde tuletati", siis tunnistas tema palge ette ilmunud töölised täievoliliseks saatkonnaks ja soovis nendega kõnelda kui tulevaste linnavolikogu liikmetega. Seepeale deklareeris Sternbeck, et eestlaste osalemisest linnavalitsuse tegevuses ei või juttugi olla, kuna kujunenud olukord on otseselt praeguste võimude tegevuse tagajärg. Pealegi ei suudaks vähesed tööliste esindajad linnavalitsuse poliitikat muuta ning tööliste esindajad kujuneksid vaid võimude jaoks sobilikuks piksevardaks, kelle peale rahva pahameel suunata. Küll aga nõuavad töölised linnavõimudelt tegevusaruannet ja õigust selle aruande õigsust dokumentide alusel kontrollida. Olles saatkonna positsiooni selgeks teinud, kandis Sternbeck ette resolutsioonis sisaldunud nõudmised.

${ }^{21}$ 5. novembril astus Riias kokku Baltimaade ühendatud maanõukogu, mis alustas Balti hertsogiriigi konstitueerimist.

22 “Tööliste saatkonnad Saksa okkupatsionivõimude juures 9. novembril 1918”, Sotsialdemokraat, $\mathrm{nr}$ 1, 12.11.1918. 
Linnapealik püüdis juttu teistele rööbastele suunata, avaldades soovi, et saadikud teeksid lõpu linnas levivatele meeleoludele, ässituskõnedele ja rahutustele, mis võivat kergesti kontrollimatuks mässuks kasvada. Seda ei saavat tema aga lubada, vaid kasutab vajaduse korral kõiki abinõusid korra säilitamiseks. Ühtlasi leidis ta, et Saksa võimuasutusi ei saa küll üleöö likvideerida, kuid Baltimaade ühendatud maanõukogu on juba astumas samme kohaliku tsiviilvalitsuse sisseseadmiseks. Küll oli aga linnapealik valmis esitama aruande senise tegevuse kohta, paludes määrata kindlaks revideerimise alguspäeva.

Sternbeck vaidles vastu, väites, et rahvast ei aja ärevusse mitte ässituskõned, vaid võimude poliitika, ning linnatänavaile toodud tugevdatud patrullid ja kuulipildujad üksnes suurendavad ärevust. Mis aga puutub Baltimaade ühendatud maanõukogusse, siis ei tunnista ükski eesti erakond selle balti aadli esinduskogu õigusi ning tsiviilvalitsuse sisseseadmisel võib jutt olla üksnes Eesti asutustele tegevusvõimaluste tagamisest. Teised saatkonna liikmed aitasid kaasa, tuues näiteid okupatsioonivõimude ebaõiglasest kaubanduspoliitikast: Eestist väljaveetavad varad ostetakse kokku turuhinnast odavamalt, sisseveetavaid esmatarbekaupu aga müüakse mitmekordse hinna eest. Linnapealik püüdis esialgu väita, et Eestist ei veetavat üldse midagi välja, kuid oli peagi sunnitud tunnistama, et tõepoolest on viidud Läänerindele toiduaineid ja Saksamaale nahku, kuid see olevat loomulik vastutasu sõjalise kaitse eest, mida Saksa väed eestlastele pakuvad. Seepeale vastas Sternbeck irooniat varjamata, et eestlased muidugi tänavad kaitse eest, kuid ei vaja seda teps mitte.

Kaks tundi väldanud kõnelused lõppesid sellega, et linnapealik märkis eestlaste nõudmised üles, et edastada need kindralkomandole ja tsiviilvalitsusele, ning lubas koostada 14. novembri hommikuks aruande, mille alusel saaksid töölised linnavalitsuse tööd revideerida.

Teine tööliste esindus eesotsas Nikolai Köstneriga pidas samal ajal läbirääkimisi toitlusameti juhataja rittmeister Kalksteiniga. Viimane teatas alustuseks optimistlikult, et elanike toitmiseks vajalikust toiduteraviljast puudub vaid kaheksandik osa ning seda puudujääki on hõlpus katta kartulite ja odra abil. Ühtlasi süüdistas ta talumehi, kes ei tahtvat põllusaadusi Saksa võimudele müüa. Just see, aga mitte toiduainete puudus või väljavedu, olevat ajutise kitsikuse põhjuseks. Kalkstein väitis koguni, et Eestist ei veetavat üldse toiduaineid Saksamaale. Talle vastu vaieldes kinnitas Köstner, et olgu teravilja väljaveoga, kuidas on, kuid võid, liha ja mune veetakse kindlasti välja ning selle kohta leidub hulgaliselt tõendeid. Samuti lükkas Köstner tagasi süüdistused põllumeeste aadressil ning leidis, et kui 
toiduaineid ei suudeta piisavas koguses hankida, siis näitab see toitlusameti saamatust ja eestlaste usaldamatust võimude vastu. Mõlemast probleemist saaks üle, kui sakslased lubaksid taastada kevadel laiali saadetud Eesti oma toitlusasutused. Kalkstein vastas, et olemasoleva organisatsiooni asendamine ei kuulu tema pädevusse, kuid lubas eestlaste soovist teavitada oma ülemaid. Ühtlasi sunniti ta tunnistama toiduainete väljavedu, väites siiski, et neid on saadetud üksnes läänerindel võitlevatele sõduritele. Ta oli valmis hankima töölisesindajatele sõiduloa Saksamaale, kus nad saaksid oma silmaga veenduda, et Eesti saadused ei lähe "Berliini rikastele". Samas avaldas rittmeister soovi, et töölised saadaksid oma esindajad toitlusametisse ning pöörduksid ajakirjanduse vahendusel talupidajate poole palvega kiirendada normivilja üleandmist. Mõlemast soovist põikles delegatsioon kõrvale, asudes seisukohale, et paari töölise lisandumine ei muudaks toitlusametit senisest usaldusväärsemaks, ning väites, et Saksa tsensuuri tõttu puuduvad eestikeelsed ajalehed, mis omaksid rahva usaldust ja suudaksid teda mõjutada. Paar tundi väldanud kõnelused lõppesid kokkuleppega moodustada uurimiskomisjon toitlusameti revideerimiseks. ${ }^{23}$

Kuna läbirääkimised linnavalitsuses ja toitlusametis kestsid pikalt, ei suutnud need rahva meeleolusid rahustada ning 9. novembri hommikul Raekoja platsile kogunenud mitmetuhande-pealine inimhulk otsustas esitada nõudmised otse kindral Seckendorffile. Saksa sõdurid tõkestasid küll meeleavaldajate tee Toompeale, kuid lubasid lossi 13-liikmelise delegatsiooni. Teiste seas kuulus sellesse Eesti iseseisvuslaste liidu üks liidreid Peeter Schneider, kes oli 1917. aastal osalenud rahvusväeosade loomisel ja nõudnud 1918. aasta algul aktiivselt Eesti iseseisvust.

Kohtumine leidis aset lossi valges saalis: "ühel pool lauda sõjamundrites Saksa võimud, teisel pool tahmaste nägudega eesti töölised ja paguniteta eesti sõjaväelased". ${ }^{24}$ Eestlased esitasid 7-punktilise nõudmiste loetelu: tagada streigi- ja sõnavabadus, sh õigus esitada poliitilisi nõudmisi; loovutada võim Eesti maanõukogule ja valitsusele; keelata Saksa vägede sekkumine Eesti asjadesse ja viia väed võimalikult kiiresti välja; mitte tunnustada Baltimaade ühendatud maanõukogu, mis esindab üksnes balti aadlit; vabastada kõik poliitvangid; kutsuda uuesti kokku Eesti sõjavägi; anda luba rahvakoosolekute pidamiseks. ${ }^{25}$

23 “Tööliste saatkonnad Saksa okkupatsionivõimude juures 9. novembril 1918”; "Kui Seckendorff üle võeti ja Dellingshausen teda manitsema lendas", 6; "Suurearvulised meeleavaldused Tallinnas"; "Toitluserahutused Tallinnas".

24 Laaman, Eesti iseseisvuse sünd, 345.

25 RA, ERA.2124.3.1875, 1. 8-9: Eesti Ajutise valitsuse tegevusse astumine 11. nov. 1918 [käsikiri, 1938]. 
Kindral Seckendorff püüdis nõudmisi blokeerida, väites, et sõja kestvusel pole võimalik Saksa vägesid välja viia, ning et seaduslik tsiviilvalitsus olevat Riias juba loomisel. Eestlased vastasid, et sõda on sisuliselt lõppenud ning et nemad tunnustavad üksnes Eesti maanõukogu võimu. Seckendorffi mõjutamiseks teatas Schneider, et Tallinnas olevat kümme tuhat eestlast üles tõusnud, manitses kindralit hoolitsema verevalamise vältimise eest ja kinnitas, et ainult sel tingimusel ei puutu eestlased ühtki Saksa sõjaväelast. Seepeale lausunud Seckendorff: "Hea küll, ma räägin teie härra Poskaga." Seega lõppes kohtumine ilma vähegi kindlamate lubadusteta. ${ }^{26}$

Saatkonna aruannet kokkusaamisest ära kuulates valgus rahvas tagasi Raekoja platsile, kus peeti veel kõnesid, muuhulgas ka Eesti iseseisvusest. Peagi sundisid aga Saksa sõjaväelased inimesed laiali minema. Õhtul suurendati Tallinnas liikunud sõjaväepatrullide arvu, mitmele poole seati üles kuulipildujad ning tänavanurkadele ilmusid ähvardavad müürilehed: kõigilt, kes esmaspäeval (11. novembril) streiki jätkavad, võetakse ära toidukaardid ja nad saadetakse tapikorras Nõukogude Venemaale. ${ }^{27}$ Niisiis ei olnud kolmandat päeva kestvad rahutused andnud mingeid silmnähtavaid tulemusi.

Kuid selsamal 9. novembril jõudis Tallinna Saksa revolutsioon, mis sai alguse madruste väljaastumisest. Seda vaatamata asjaolule, et Saksa mereväelasi leidus Tallinnas napilt - vaid üks mereväekompanii (Marinekompagnie), kergeristleja Stralsund ja miinipanija Nautilus (kummagi laeva meeskonnad ei osalenud järgnenud sündmustes). Olles raadiotelegraafi vahendusel saanud teateid Saksamaa sündmustest, pidas mereväekompanii meeskond hommikul ära koosoleku, kus arutati kodumaale pöördumise võimalusi. Pärastlõunal heiskasid madrused sadamas punase lipu ja valisid mereväelaste komitee, mis esitas ülematele konkreetsed nõudmised: "1) et neid koju lastaks, 2) et neile ohvitseridega ühesugust sööki antaks, 3) et auandmine ära kaotataks." ${ }^{28}$ Seckendorff saatis sadamasse usaldusväärseks peetud Baieri jalaväelased, kes tõkestasid küll madruste linnapääsu, kuid keeldusid kasutamast jõudu mereväelastest kamraadide vastu. Õhtuks saavutas parasjagu Tallinnas viibinud Balti mere sõjajõudude juhataja viitseadmiral Ludolf von Uslar kokkuleppe, mille kohaselt tõmmati jalavägi sadamapiirkonnast välja ning madrused asendasid punalipu uuesti Saksa sõjalipuga.

\footnotetext{
26 Laaman, Eesti iseseisvuse sünd, 345.

27 "Suurearvulised meeleavaldused Tallinnas"; "Kui Seckendorff üle võeti ja Dellingshausen teda manitsema lendas", 6 .

28 "Saksa sõjaväelaste nõukogu", Tallinna Teataja, nr 63, 11.11.1918.
} 
10. novembril süvenes revolutsiooniline meelsus Saksa sõjaväelaste seas veelgi ning õhtul toimunud suurel koosolekul moodustati Tallinna garnisoni Saksa soldatite nõukogu. Edaspidi istus see koos Toompea lossis ja ilma tema kaasallkirjata ei kehtinud ükski kindralkomando korraldus. Näis korduvat protsess, mis aasta varem päädis Vene armee (ja riigi) kollapsiga. Olukorda pingestasid veelgi mitmesugused kuulujutud - kardeti nii Vene punalaevastiku rünnakut Tallinnale kui ka eestlaste kallaletungi toitlusametile. Igaks juhuks seati kõik väeosad lahinguvalmidusse ja sadamas seisnud sõjalaevad klaariti kiireks väljasõiduks. ${ }^{29}$

Ülistatud Preisi distsipliini kokkuvarisemine tekitas Saksa staapides segadust. Vähemalt sedavõrd, et kindral Seckendorff otsustas eelmisel päeval eestlastele mokaotsast poetatud lubaduse teoks teha ja kutsus enda jutule Jaan Poska. Kokkusaamise käik on tuntud Eduard Laamani kahe kirjelduse läbi. Jaan Poska eluloos tugines Laaman Poska enda jutustusele, mis on fikseeritud ka ajutise valitsuse 11. novembri istungi protokol$\operatorname{lis}^{30}$, ning väitis, et Seckendorff olevat teatanud, et ta käskis tallinlaste toidunorme suurendada, ja küsinud, kas sellest piisab rahva rahustamiseks. Kui Poska arvanud, et rahustamise peamiseks eelduseks on maanõukogu kokku kutsumine, jäänud kindral esiotsa kõhklema, kuid andnud mõni tund hiljem kirja teel teada, et selleks takistusi ei ole. ${ }^{31}$ Suurteos "Eesti iseseisvuse sünd" kirjeldas kohtumist pisut teisiti: Seckendorff palunud nõu ja abi tööliste rahustamiseks ning kui Poska vastas, et tal on vaja nõu pidada, kindral ärritunud: "Teie tahate niisiis surnud Eesti valitsust jälle kokku kutsuda?" Poska seletused, et tema üksi ei suuda midagi teha, küll leevendasid pinget, kuid kohtumine lõppes siiski tulemusteta. Paar tundi hiljem saanud aga Poska kirja, milles Seckendorff soostus ajutise valitsuse kogunemisega, ent vannutas: "Ärge Jumala pärast midagi tehke, enne kui minuga olete läbi rääkinud." 32 Seega, kui esimese kirjelduse kohaselt andis Seckendorff nõusoleku maanõukogu, siis teise järgi hoopiski ajutise valitsuse kokku kutsumiseks. Millest säärane oluline erinevus muidu detailitäpse ja usaldusväärse Laamani kirjeldustes tuleneb, pole teada.

\footnotetext{
29 RA, ERA.2124.3.1875, 1. 1-3: Eesti Ajutise Valitsuse tegevusse astumine 11. nov. 1918 [käsikiri, 1938]; RA, ERA.2124.3.1727, pag-mata: Väljavõtted kindralkomando 68 sõjapäevaraamatust, 10.-11.11.1918; "Kohalik Saksa sõjaväelaste nõukogu”, Tallinna Teataja, nr 65, 13.11.1918.

30 RA, ERA.31.1.8, 1. 11: Ajutise Valitsuse koosoleku protokoll, 11.11.1918.

31 Eduard Laaman, Jaan Poska, Eesti riigitegelase elukäik ([3. trükk] Tartu: Eesti Kirjanduse Selts, 1998), 78.

32 Laaman, Eesti iseseisvuse sünd, 347.
} 


\section{Ajutine valitsus alustab taas}

Ajutine valitsus taasalustas tööd 11. novembril. Seejuures ei olnud tegemist sügava saladuskatte all hoitud sammuga, sest isegi rahva seas saksameelseks põlastatud ja Saksa tsensuuri kindlas haardes tegutsenud Tallinna Päevaleht tõi lugejateni napisõnalise teate: "Nagu meie kuuleme, astuvat täna Eesti ajutine valitsus kokku ja võtvat maa juhtimise enese kätte." 33

Veelgi selgema tõendi olukorra muutumisest andis asjaolu, et protestiks sõnavabaduse kaotamise vastu seisma jäänud Tallinna Teataja ilmus 11. novembril uuesti, kusjuures võimudelt luba küsimata. Tsensoritest sõltumatuna ja vast ka paremini informeerituna jagas Tallinna Teataja oma lugejatele rohkem teavet. Kaheküljeline lehenumber algas pilkupüüdvate pealkirjadega: "Eesti Maapäev astub kokku." - "Sõjariistaderahu alla kirjutatud." - "Saksa keiser troonilt ära astunud. Riigikantsleriks sotsialdemokrat Evert." - "Soomes vabariik välja kuulutatud." Järgnes lühiteade ajutiselt valitsuselt: "Eesti Maapäeva kokkuastumiseks on Saksa sõjaväevõimude poolt J. Poska ja K. Pätsi nime peale luba tulnud." ${ }^{34}$ Pikemalt iseloomustas olukorda toimetuse liige Jaan Lintrop, kirjutades muuhulgas: "Eesti ajutine valitsus astub täna kokku ja võtab maa valitsemise oma kätte. Ministritest on kohal: välisminister J. Poska, põllutööminister Dr. J. Raamot, rahaminister J. Kukk ja teedeminister F. Peterson. Pea- ja siseminister K. Päts ei ole veel Saksa vangist, kust ta kuuldavasti mõni päev tagasi vabastatud, koju jõudnud, tema aset täidab seni J. Poska. Kohtuminister J. Vilms ja sõjaminister A. Larka viibivad praegu väljamaal. Kaubandus-tööstuse ja mereministri kohad on esialgu veel vabad, aga võib loota, et nende ametite peale juba lähemal ajal kohased isikud määratakse."35

Kuigi Lintropi informatsioon polnud päris täpne, oli tal õigus peamises. 11. novembri hommikul kogunesid Tallinnas viibinud ajutise valitsuse liikmed teedeminister Ferdinand Petersoni korterisse kaupmees Georgi Gutkini majas (Viru tn 4) ja pidasid üle mitme kuu valitsuskabineti istungi. Tõsi, veebruaris ametisse nimetatud üheksast ministrist osalesid koosolekul vaid neli (välisminister Jaan Poska, põllutöö- ja toitlusminister Jaan Raamot, raha- ja riigivaranduste minister Juhan Kukk ning teedeminister Ferdinand Peterson), lisaks kaks täiendavalt valitsusse koopteeritud meest (kohtuministri kt Jüri Jaakson ja kaubandus-tööstusministri kt August Hanko). Kohal olid ka põrandaaluse kaitseliidu juhid (Johan Pitka, Ernst

\footnotetext{
33 “Eesti ajutise valitsuse kokkuastumine”, Tallinna Päevaleht, nr 122, 11.11.1918.

34 Tallinna Teataja, nr 63, 11.11.1918, 1.

35 Jaan Lintrop, “Eesti ajutine valitsus...", Tallinna Teataja, nr 63, 11.11.1918.
} 
Põdder, Aleksander Seiman) ning veel mõned enam- või vähemtuntud isikud, nagu Estonia seltsi esimees Jaan Linnamägi, sotsiaaldemokraat Nikolai Köstner ja tööerakondlane Rudolf Paabo. Mõningatel andmetel osalesid ka Konstantin Konik ja Otto Strandman ${ }^{36}$, ehkki istungi protokollis nende nimed ei kajastu. Koosolekut protokollis valitsuse asjadevalitseja Eduard Laaman.

Istung kandis teavituslikku iseloomu. Alustuseks andis Jaan Linnamägi teada kokkusaamisest baltisakslaste esindajatega, kes olnud mures Saksa vägedes valitseva meeleolu pärast: "Saksa väed, iseäranis baierlased tahta koju minna, väeülemustel ei olla nende kohta enam võimu." Seejärel teavitas Jaan Poska läbirääkimistest kindral Seckendorffiga ning lisas, et tema isiklikult jääb kindlaks kavatsusele valitsusest lahkuda, kuna teda on liig palju laimatud. Teedeminister Peterson andis teada, et on määranud Tallinna sadama komandandiks kaugesõidukapten Oskar Treilmanni ${ }^{37}$. Ohvitserid Põdder ja Seiman jagasid teavet Narva jõe idakaldal leiduvate punaarmee väeosade kohta ning kinnitasid, et Saksa soldatite nõukogu on otsustanud kaitsta Narva jõe joont seni, kuni neilt kaitsekohustus üle võetakse. Johan Pitka teatas, et töölised kavandavad rahvuslike varade väljaveo takistamiseks streiki ning et Tallinna sadama raadiojaama on saabunud telegramm, mille kohaselt olevat Briti laevastik teel Läänemerele. Nikolai Köstner ja Rudolf Paabo informeerisid valitsust kavatsusest kutsuda kokku Tallinna linnavolikogu. Seepeale läkitati Köstner koos rahaminister Kukega linnapealik Schmidti jutule. Kuna raekoda paiknes vaid mõne sammu kaugusel, siis jõudsid mehed peagi tagasi ja teatasid, et pärast mõningast puiklemist nõustus Schmidt raekoja saali volikogu käsutusse andma.

Otsustati: kiita heaks Treilmanni nimetamine sadamakomandandiks; määrata polkovnik Jaan Soots sõjaministri ajutiseks kohusetäitjaks; kohustada kõiki ministreid ametisse jääma kuni maanõukogu või selle vanematekogu kabineti ümber kujundab; volitada rahaministrit kõnelema sotsiaaldemokraatidega valitsuse täiendamise üle; korraldada maanõukogu vanematekogu koosolek 12. novembril; anda politseilised funktsioonid üle omavalitsuste pädevusse; asendada Tallinna omakaitse (Bürgerschutzwehr) Eesti kaitseliiduga; pidada valitsuse järgmine istung 12. novembril. Ühtlasi otsustati toimuvast teavitada rahvast. ${ }^{38}$

36 Konstantin Konik, "Mälestuste katkendid", Mälestused iseseisvuse võitluspäivilt, I: revolutsioon ja okupatsioon 1917-1918 (Tallinn: Eesti Ajakirjanikkude Liit, 1927), 26.

37 Oskar Treilmann oli juba oktoobris saanud Johan Pitkalt korralduse valmistuda Eesti sadamate ülevõtmiseks sakslastelt (Reet Naber, Johan Pitka: ausa tahtega isamaa heaks! (Tallinn: TEA 2012), 181).

38 RA, ERA.31.1.8, 1. 11, 13: Ajutise Valitsuse koosoleku protokoll, 11.11.1918. 


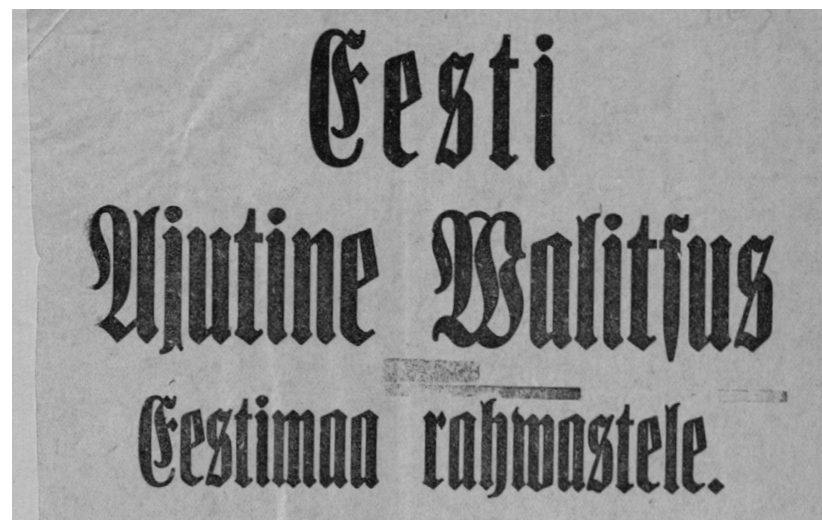

Eesti Maapäetra פanemate Nõutogu fitufutas 24, weebruaril 7. a. manifesti läbi Cesti ifefeismats Demotraatlifets wabariigifs ia

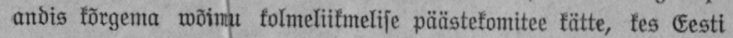

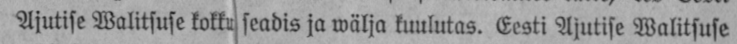
wälisfaattonna ettepmefur tunnistafio Yittriigio Eesti Maapäewa

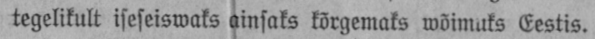

Seega annah Eisti 2ijutine WBalitfus teaba, et ta oma talistatuto tegewuif mueste ont agamuo ja awaloab järgmift:

1. Sähemater premadel astub foffit Eesti Maapäem, felle pea-

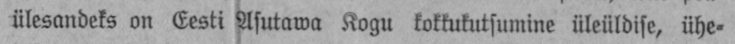

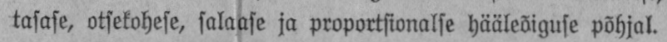

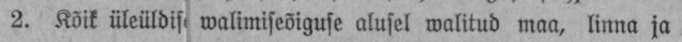
walla ontawalitfuje autujed peawas ajawiitmata oma fatfestatuo

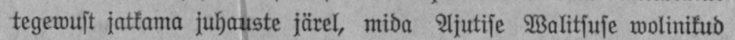
fohtabel annawas. Whajepeal tegewujes olnuo ametiajutustelt ia ififitutelt tuleb asjaajamme iilewortta.

3. Kjutinte $23 a$ alitus futfub Eesti rabwaiłt rabuliêtu ufardurjega Ijutife $23 a$ alitfufe wasthtustifait tegemuift toetama ja forba jegawateft wäliaastumisteft tagafi joioma. Maa ja rabwa faitjefs on fammufio

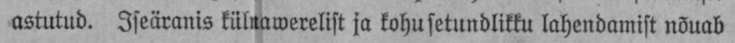

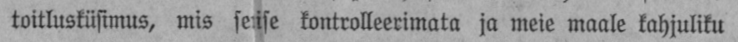

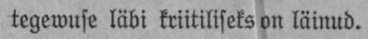

Eesti 2jutine Waitius Ioodab, et Eesti rahyas fel futurel ajaloolifel filmapilgul ma enejemääramije õiguft fulturalijelt tarwitaba ostab.

Tallintas, 11. nowanbril 1918.

Eesti 2 jiutije $\mathfrak{B}$ Balitfufe molitujer:

3. Pogfa.

פr. Sdifferi trilt, Tallintas,

Joonis 1. Ajutise valitsuse esimesel istungil 11. novembril 1918 koostatud pöördumine Eestimaa rahvastele (RA, ERA.534.1.29, 1.162). 
Viimase otsuse täitmiseks koostati pöördumine "Eesti Ajutine Valitsus Eestimaa rahvastele”, millele kirjutas alla Jaan Poska. Kuna iseseisvuse väljakuulutamine oli toimunud segastes oludes ja võis karta, et teave toimunust polnud veel kõigi inimesteni jõudnud, siis anti pöördumises teada, et maanõukogu vanematekogu kuulutas iseseisvusmanifesti läbi välja iseseisva Eesti vabariigi ja nimetas ametisse päästekomitee, mis omakorda kujundas ajutise valitsuse. Ühtlasi kinnitati, et 24. veebruaril ametisse seatud valitsus alustab uuesti tegevust ja juba lähipäevil koguneb ka maanõukogu, mille peamiseks ülesandeks jääb asutava kogu kokku kutsumine. Kohalikel omavalitsustel kästi jätkata katkestatud tegevust, lähtudes ajutise valitsuse volinike korraldustest. Rahvast kutsuti üles toetama valitsust ja hoiduma avalikku korda häirivatest väljaastumistest. ${ }^{39}$

Siitpeale sai alguse ajutise valitsuse järjepidev töö omariikluse ülesehitamiseks. Valitsuse järgmine istung peeti juba 12. novembri hommikul, sedapuhku Jaan Raamoti 9-toalises härraskorteris (tänapäeval Roosikrantsi 10). Sellele istungile jõudis lisaks päev varem osalenud kuuele ministrile ka eelmisel õhtul Tartust teele asunud haridusminister Peeter Põld. ${ }^{40}$ See lubab kinnitada, et vaatamata sideliinide allutamisele Saksa sõjaväe rangele järelevalvele leidus kanaleid, mille abil eesti poliitikud omavahel ühendust pidasid. Protokolli järgi otsustades osalesid koosolekul ka mõned valitsusse mittekuulunud inimesed, nagu endine päästekomitee liige Konstantin Konik ning kaitseliidu esindajad Rudolf Reiman ja Johan Unt.

Seegi istung oli põhiliselt informatsioonilist laadi. Polkovnikud Reiman ja Unt andsid teada, et kaitseliit alustab patrullimist Tallinna tänavail ning et liidu juhatus on kaalunud võimalust moodustada mingit laadi sõjaväeüksus. Doktor Konik ja minister Kukk rääkisid eelmisel õhtul toimunud kokkusaamisest Saksa soldatite nõukogu liikmetega. Sakslased kinnitanud, et distsipliin olla täies korras. Nõukogu ei taha ennast maa sisepoliitikasse segada, vaid ainult korda alal hoida. Mingit enamlist mässu ei lubatavat. ${ }^{41}$ Sellele positiivsele infole lisas Juhan Kukk ärevust teatega, et Dvigateli ja tselluloosivabriku töölised kavandavad keskpäevaks valitsusevastast meeleavaldust. Mainimist leidis ka sada matööliste seas valitsenud ärevus, mis tulenes varade väljaveo jätkumisest.

Otsustati: 1) tunnistada tarvilikuks Eesti sõjaväe korraldamine kaitseliidu baasil; 2) nimetada kindral Põdder sõjaministri ajutiseks asetäitjaks ${ }^{42}$;

\footnotetext{
39 "Eesti Ajutine Valitsus Eestimaa rahvastele, 11.11.1918", Riigi Teataja, nr 1, 1918, 2-3.

40 "Eesti Ajutine Valitsus maavalitsuse oma kätte võtnud", Postimees, nr 213, 12.11.1918.

41 RA, ERA.31.1.8, 1. 3: Ajutise valitsuse koosoleku protokoll, 12.11.1918.

42 Eelmisel päeval samale ametikohale määratud polkovnik Jaan Soots viibis haigena (Eestis, nagu kogu Euroopas, möllas gripipandeemia, nn hispaania haigus) isatalus
} 
3) jätta Tallinna komandandi määramine kaitseliidu juhatuse lahendada; 4) kontakti loomiseks kaitseliidu ja Saksa soldatite nõukogu vahel komandeerida nõukogusse kindral Põdder; 5) jõuda soldatite nõukoguga kokkuleppele, et nad tegutseksid käsikäes ajutise valitsusega; 6) saata Riiga volinik läbirääkimisteks Saksamaa esindajaga väljaveo lõpetamise ning varade ja asutuste üleandmise küsimuses; 7) volitada teedeminister Petersoni "Saksa radioga ühendus luua" (arvatavasti loodeti võtta üle Saksa sõjaväe valduses olnud raadiojaamad); 8) teha maanõukogu vanematekogule ettepanek kutsuda maanõukogu kokku 20. novembriks ja täiendada ajutise valitsuse koosseisu. ${ }^{43}$

12. novembri pärastlõunal kogunes Estonia seltsimajja maanõukogu vanematekogu. Kohal olid kõigi erakondade (v.a enamlased) esindajad, kokku 16 inimest, sh kuus ministrit (kõik peale Poska). Päevakorras oli kolm küsimust: valitsuse tegevusaruanne, maanõukogu kokku kutsumine ning valitsuse täiendamine. Valitsuse aruande esitas rahaminister Kukk. Ta tõdes, et okupatsioonivõimu esialgne nõrkus võimaldas ajutisel valitsusel veebruaris-märtsis lühikest aega töötada, kuid peagi oldi sunnitud minema põranda alla. Sellest hoolimata suutis valitsus juhtida mõningaid aktsioone, mis olid suunatud Balti hertsogiriigi rajamise ja Eesti Saksamaaga ühendamise vastu. Põhitähelepanu pööras Kukk välisdelegatsiooni tegemistele, mille tulemuseks oli de facto tunnustus maanõukogule Suurbritannia, Prantsusmaa ja Itaalia valitsustelt. Riigikaitse küsimusi puudutades teatas aruandja, et ehkki valitsus otsustas kutsuda lisaks kaitseliidule ellu ka alalise kaitseväe, peab esialgu "võeras vägi abiks tulema, kuid see ei tohi mitte Saksa vägi olla, keda meie ei taha". Toitlusprobleemi lahendamiseks oli välisdelegatsioon pöördunud Briti ja Ameerika valitsuste poole palvega anda luba 10 ooo tonni teravilja sisseveoks Eestisse.

Aruandele järgnenud läbirääkimistel ei lahatud mitte valitsuse ega välisdelegatsiooni tegevust, vaid arutleti mitmesuguste kuulduste ja võimalike arengute üle. Radikaaldemokraat Ado Birk kõneles äsjasest enamlaste demonstratsioonist, mille sakslased laiali ajasid, ja linnas levi(tata) vatest kuulujuttudest, nagu oleksid ka Prantsuse armee ja Briti laevastik sattunud revolutsioonikeerisesse. Tööerakondlane Aleksander Veiler, maaliitlane Jaan Teemant ja haridusminister Põld juhtisid tähelepanu hädaohule, mis võib Eestit ähvardada vene valgete poolt, kes panustavad ühtse

Viljandimaal. Nähtavasti ei jõudnud ka kindral Põdder sõjaministrina tööle asuda, kuna oli tegev kaitseliidus. Pealegi jõudis sõjaminister Larka 13. novembril kodumaale (vt RA, ERA.2124.3.1846: Sõjaministeeriumi kujunemine [käsikiri], dat-mata).

43 RA, ERA.31.1.8, 1. 3-4: Ajutise valitsuse koosoleku protokoll, 12.11.1918. 
ja jagamatu impeeriumi taastamisele. Minister Raamot andis ülevaate oma käigust toitlusametisse ja maapealiku juurde, kus selgus, et Tallinnas jätkub toiduaineid vaid kolmeks päevaks. Sellele vaatamata tõrkunud sakslased toitlusametit üle andmast, kuna polevat saanud vastavat korraldust. Konstantin Konik, keda protokollis tervishoiuministriks tituleeriti, nõudis, et kõige kiiremas korras võetaks sakslastelt üle post, sadam ja raudtee, "sest ilma liikumisevõimaluseta on võimata linna toitmist oma pääle võtta".

Pikema jututa kiideti heaks valitsuse ettepanek kutsuda maanõukogu kokku 20. novembriks ning pidada istungjärk Toompea lossis. Ametisse määrati isegi Toompea lossi komandant (Eduard Laaman). Seejärel jõuti ajutise valitsuse täiendamise küsimuse juurde. Alustuseks tehti teatavaks kabineti koosseis 12. novembri seisuga, konstateerides vajadust nimetada ametisse töö- ja hoolekandeminister, kaubandus- ja tööstusminister ning kohtuminister. Kahte ministri kohta sooviti pakkuda sotsiaaldemokraatidele. Vastuseks kinnitas Nikolai Köstner, et nende partei võiks valitsusse tulla ainult siis, kui tööliste poolt peaks selleks sooviavaldus olema, kuid lisas, et töölised nähtavasti ei takistaks seda sammu tingimusel, et valitsus "järgmised lubadused annab: 1) A[jutine] V[alitsus] kohustab ennast kõiki vabadusi kaitsma, 2) valimise õigust ei kärbita, 3) töökaitse seadus, mis Kerenski ajal maksis, saab uuesti maksma pandud". Juttu tuli ka Jaan Poska lahkumissoovi tagamaadest ehk tööerakondlaste, eriti Jüri Vilmsi, teravatest rünnakutest Poska vastu 1917. aastal, kusjuures leiti, et Poska peaks siiski valitsusse jääma. Lõpuks otsustati "J. Poskat paluda kohtuministri kohta vastu võtta, kaub.-tööst. ja töö- ja hoolek. ministrite kohad aga s[otsiaal]-d[emokraati]-de jaoks vabaks jätta”.

Sisuliselt seadis maanõukogu vanematekogu 12. novembril ametisse ajutise valitsuse teise koosseisu. Sellesse kuulusid peaminister Päts (kohusetäitja Poska); siseminister Päts (kohusetäitja Kukk), sõjaminister Larka (kohusetäitja Põdder), välisminister Strandman, haridusminister Põld, teede ja tehnikaminister Peterson, kohtuminister Poska, põllutöö- ja toitlusminister Raamot, rahaasjanduse minister Kukk; portfellita minister Tõnisson. Kaubandus-tööstus- ja töö-hoolekandeministri kohad reserveeriti sotsiaaldemokraatidele ${ }^{44}$.

Koosoleku lõpuks jõudsid tagasi kindral Seckendorffi jutul käinud ministrid Kukk ja Peterson. Nad teatasid, et Seckendorff on nõus ajutist valitsust omalt poolt tunnustama, jättes lõpliku otsustusõiguse Saksamaa valitsusele. Samuti on kindral valmis andma üle toitlusameti ja "sisemised

44 16. novembril nimetati kaubandus- ja tööstusministriks Nikolai Köstner ning töö- ja hoolekandeministriks Aleksander Tulp. 
valitsusasutused", lisaks veel Tallinna ja saarte vahel ühendust pidava laeva ning relvastust. Seevastu raudteed, sideühendusi ja Toompea lossi keeldub Seckendorff loovutamast (lossi asemel pakub ta eestlastele endist mereväeklubi Suurel turul). Homme, 13. novembril, kell 11 algavad maapealiku juures läbirääkimised üleandmiste asjus. ${ }^{45}$

Ajutise valitsuse istungi ja maanõukogu vanematekogu koosoleku vahelisel ajal oli Tallinnas leidnud aset sündmus, mis ei ennustanud loodavale Eesti vabariigile midagi head. Eelnenud päevade streigid ja meeleavaldused olid ärgitanud aktiivsele tegutsemisele enamlasi. Nende arvukus ja populaarsus olid okupatsioonikuudel küll kokku kuivanud ning nende juhid olid kodumaalt põgenenud, otsides karjäärivõimalusi Nõukogude Venemaal. Siiski leidus vähemtuntud enamlikke tegelasi Eestiski. Oktoobris Moskvas toimunud okupeeritud alade kommunistide konverentsil peetud ettekandes väitis Jaan Sihver, et parteiorganisatsioonid tegutsevat Tallinnas (umbes 200 liiget), Narvas (40), Tartus (10), samuti Rakveres ja Pärnus. ${ }^{46}$

Tallinna enamlased olid loonud kontakti äsja moodustatud Saksa soldatite nõukoguga ja teinud sellele ettepaneku ühineda kommunistliku töölisliikumisega. Positiivset vastust siiski ei saadud ja mõõdukate sotsiaaldemokraatide mõju all olnud nõukogu kinnitas, et "Saksa sõjaväelased ei tahtvat endid kohalikusse sisepoliitikasse segada. Nad tahtvat siit ainult täies korras ja võimalikult pea koju minna" ${ }^{47}$ Pettumine sakslaste hoiakutes enamlasi ei heidutanud ja nii otsustasid nad korraldada 12. novembril ajutise valitsuse vastase meeleavalduse. Ent Saksa väejuhatus ei kavatsenud rohkem meeleavaldusi lubada. Seda enam, et linnas liikusid kuuldused, nagu oleks väljaastumine suunatud Saksa võimude vastu. Tallinna kesklinnas suurendati relvastatud patrullide arvu ja siin-seal seati üles kuulipildujad. Keskpäeva paiku ilmus Vene turule tuhatkond enamlaste poolehoidjat (suuremalt jaolt Dvigatelist) punaste lippude ja Ajutise valitsuse vastaste loosungitega. Sakslased nõudsid meeleavaldajate laialiminekut, kuid nood ei allunud korraldusele, vaid olevat koguni püüdnud hõivata Musumäel asunud kuulipildujat. Seepeale avasid sakslased hoiatustule õhku. Tekkinud rüsinas sai üks inimene vigastada ja mõned enamlike loosungitega lipud rebiti puruks. ${ }^{48}$ Seega kukkus ettevõtmine läbi enne, kui sai õieti alatagi.

45 RA, ERA.78.1.49, lk 123-136: Maanõukogu vanematekogu koosoleku protokoll $\mathrm{nr}$ 49, 12.11.1918.

46 "Jaan Sihveri ettekanne, 22.10.1918", Kodusõda ja välisriikide interventsioon Eestis 1918-1920: dokumente ja materjale, I (Tallinn: Eesti Raamat 1984), 83.

47 "Saksa sõjaväelaste nõukogu".

48 Revolutsioon, kodusõda ja välisriikide interventsioon Eestis (1917-1920), II (Tallinn: Eesti Raamat, 1982), 134; Helmuth Veem, "Võitlus põrandaalustega”, Mälestused 
Kuid see ei tähendanud kaugeltki enamlaste taandumist. Vastupidi, jäädi ootama uusi võimalusi oma poliitilise platvormi teostamiseks.

Muidugi polnud kaugeltki mitte kõik Tallinna tehased ja töölised enamlaste selja taga. Mitmed suurettevõtted (Johansoni paberivabrik, Krulli masinatehas, Mayeri keemiavabrik) jätkasid tööd ning mõnel pool (raudteetehastes, Pitka laevatehases) korraldati tööseisak mitte enamlaste, vaid ajutise valitsuse toetuseks. Raudteetöölised ja -ametnikud võtsid 11. novembril vastu resolutsiooni: "tahame tänasest tunnist ainult Eesti ajutise valitsuse käskusid kuulda ja tema otsusi täita. [...] protesteerime igasuguse Eestimaalt varanduste väljaviimiste vastu ja võtame kogu Eestimaa varanduse väljaviimise, mis raudtee kaudu sünnib, oma valve alla". ${ }^{9}$

12. novembri pärastlõunal kogunesid uuesti linnavalitsuse ja toitlusametiga läbirääkimisi pidanud töölisesindajad, kuid sedapuhku oli päevakorras varade väljaveo takistamine ja suhtumine ajutisse valitsusse. Esimeses küsimuses jõuti kiiresti üksmeelele: "Tallinna töölised teatavad, et nemad kõik oma jõu kokku võtavad, et rahva varanduste ja toiduainete väljavedu Eestist kõigi abinõudega takistada ja isegi üleüldise streigi ees tagasi ei põrka.” Teine küsimus polnud nii üheselt lahendatav. Muuhulgas küsiti koosolekul viibinud teedeminister Petersonilt, mida on valitsus teinud tööliste olukorra parandamiseks ja kas 1917. aastal kehtestatud töökaitseseadused hakkavad uuesti kehtima. Peterson tunnistas, et valitsus pole jõudnud neid küsimusi arutada, kuid arvas, et seadused jõustatakse. Koosolek asus seisukohale, et enne lõplikku otsustamist tuleb selgitada välja valitsuse kavatsused töökaitseseaduste osas..$^{50}$

Ehkki ajutine valitsus oli juba kaks päeva avalikult tegutsenud, polnud Saksa võimude suhtumine sellesse ikka veel selge. 11. novembri keskpäeval helistati Riias viibinud Eestimaa rüütelkonna peamehele Eduard von Dellingshausenile, kes oli mõne päeva eest valitud Baltimaade ühendatud maanõukogu esimeheks, 8 . armee staabist ja soovitati tal viivitamatult sõita Tallinna, et takistada kindral Seckendorffi eestlaste nõudmistele järele andmast. Väejuhatus andis Dellingshauseni käsutusse sõjaväelennuki ja nii koges parunihärra esmakordselt elus õhusõitu. See ei kulgenud aga loodetud moel, sest ilmastikuolud sundisid lendurit tegema Tapa mõisa väljadel hädamaandumise ning Dellingshausen jõudis Tallinna alles 12. novembri hommikuse rongiga. "Kohe pärast saabumist läksin kindral v. Seckendorffi

iseseisvuse võitluspäevilt, II: Vabadussõda 1918-1920 (Tallinn: Eesti Ajakirjanikkude Liit, 1930), 287; “Tallinna sõnumid”, Tallinna Päevaleht, nr 124, 13.11.1918; RA, ERA.2124.3.1727, pag-mata: Väljavõtted kindralkomando 68 sõjapäevaraamatust, 12.11.1918.

49 "Ärakiri protokollist", Sotsialdemokraat, $\mathrm{nr}$ 1, 12.11.1918.

50 "Vabrikute esitajate teine koosolek", Sotsialdemokraat, $\mathrm{nr}$ 1, 12.11.1918. 
juurde, kelle leidsin murtud meeleolus ja energiliseks tegutsemiseks võimetuna," meenutas Dellingshausen hiljem. Seepeale otsis ta toetust maapealik von Zahni ja Seckendorffi staabiülema major Hermann Ritter von Pfistermeisteri juures ning üheskoos üritati kindralit veenda, et tal tuleks maanõukogu kogunemiseks antud luba tühistada. Seckendorff jäi kõhklevale seisukohale ega söandanud otsustavaid abinõusid rakendada, olles veendunud, et sõdurid ei kuuletu tema käskudele ega ole valmis kasutama vägivalda. Õhtupoolikul helistas Seckendorff Dellingshausenile ja teatas, et on otsustanud eestlaste nõudmistele vastu tulla. ${ }^{5}$ Samal õhtul läkitaski kindral Jaan Poskale ametliku kirja, milles öeldi: "Endise Maapäeva liikmetel on lubatud kokku astuda, et pidada nõu ettepanekute üle, kuidas tulevast maavalitsust kujundada. Kokku kutsumine ei tähenda veel uue valitsusvõimu tunnustamist." ${ }^{\prime 52}$

13. novembri hommikul kleebiti müürilehtedena Tallinna tänavatele kindralkomando ja provintsivalitsuse ühine teadaanne: "Selle järele, kui täna hommiku "Maapäeva" kokkuastumine lubatud, loetakse nüüd Ajutine Eesti Valitsus olemasolevaks, arvamises, et Saksa valitsus selle hiljem maksvaks tunnistab. Tema on maa varustamise Keskkoha üle võtnud. Saab kindlaste oodatud, et nüüdsest peale edaspidised rahurikkumised kindlaste kõrvale hoitakse." ${ }^{53}$

Tõenäoliselt oli säärane ootamatu järeleandlikkus tingitud 12. novembril järsult kasvanud ärevusest. Nimelt peeti pärastlõunal Tallinna garnisoni üldkoosolek, millele järgnes soldatite nõukogu istung. Mõlemad toimusid käremeelses õhkkonnas, kus nõuti viivitamatut tagasipöördumist kodumaale. Koosolekutel osalenud Saksa ohvitser järeldas: sõdurite seas on ülekaalu saavutanud radikaalsed elemendid, juhtimine on seniste juhtide käest ära libisenud ja väeosad ei astuks mingi juhul jõuga ei eesti rahvuslaste ega enamlaste vastu. Selliste meeleolude tulemusena avaldas kindralkomando soovi, et Briti laevad võimalikult pea Tallinna tuleksid, ning provintsivalitsuse ohvitserid otsustasid kohe Riiga sõita, jättes võimu üleandmist korraldama vaid kolm juhtivametnikku (neistki olevat üks omavoliliselt lahkunud)..$^{54}$

Toimunus sügavalt pettunud Eduard von Dellingshausen astus 14 . novembril Eestimaa rüütelkonna peamehe kohalt tagasi. Tema asemele valiti Kuusiku mõisa omanik Otto von Lilienfeld, kes polnud varem

51 Dellingshausen, Kodumaa teenistuses, 206-208.

52 "Kindral Seckendorff Jaan Poskale, 12.11.18", Eesti rahvusväeosade album, III (Tallinn, 1938), 97.

53 "Eesti valitsuse tegevusest", Päevaleht, $\mathrm{nr} 24,13.11 .1918$.

54 RA, ERA.2124.3.1875, 1. 4-5. 
poliitikas kaasa löönud ja näis olevat muutunud oludes sobivaim isik. Siiski pöördus Dellingshausen veel enne lõplikku lahkumist rüütelkonna komitee nimel kirjalikult Saksa sõjaväelise juhtkonna poole palvega kaitsta läbirääkimistel eestlastega baltisakslaste (vähemusrahvuste) õigusi ja huve. ${ }^{55}$

Seda palvet püüdsid juhtivad Saksa sõjaväelased edaspidi võimalust mööda täita, kusjuures alustuseks tuli neil välja astuda parun Dellingshauseni enda kaitseks. Nimelt sai Dellingshausen 15. novembril Tallinna miilitsaülemalt ettekirjutuse, millega tal keelati ilma ajutise valitsuse loata Tallinnast lahkuda (Dellingshausenit käsitleti omamoodi pantvangina, keda ei tahetud maalt välja lubada enne, kui peaminister Päts on vabastatud). Asjaosaline pöördus abipalvega major Pfistermeisteri poole. Viimane soovitas vältida avalikku konflikti ning vastata, et Dellingshausen ei kavatse hetkel Tallinnast lahkuda ning kui selline vajadus peaks tekkima, teavitab valitsust 12 tundi ette. ${ }^{56}$

Lisaks läkitas major Pfistermeister soldatite nõukogu nimel ajutisele valitsusele kirja, milles öeldi: "Vastavalt Saksa rahvavalitsuse korraldusele kindlustab okupatsiooniarmee nüüd ja edaspidi Eestimaal elunevate riigisakslaste ja saksa soost elanikkude kaitse ning isikliku vabaduse. Armee ei luba, et nendel elanikerühmadel tekiks oma rahvuse pärast [...] ebameeldivusi. Eriti nõuab okupatsiooniarmee nendele elanikerühmadele vabadust otsustamiseks, kas, millal ja kuhu nad sõita tahavad. Okupatsiooniarmee avaldab lootust, et kõik selle nõudmisega vastuolus seisvad Eesti valitsuse käsud otsekohe tühistatakse, vastasel korral oskab ta oma hõimukaaslaste elu, vabadust ja omandit relvadega kaitsta." ${ }^{57}$ Viimane lause oli sõnaselge ähvardus, kusjuures torkab silma, et relvi lubati kasutada mitte üksnes sakslaste elu, vaid ka nende vara kaitseks. Küllap oli siin otsene seos balti mõisnike murega oma maavalduste saatuse pärast. Ajutine valitsus arutas ähvarduskirja 19. novembril ja tegi välisministrile ülesandeks vastata soldatite nõukogule, et "valitsus ei ole ühtegi määrust väljaandnud, mis Saksa soost elanikka ähvardaks". ${ }^{58}$ Parun Dellingshauseni suhtes kohaldatud lahkumiskeeld tühistati pärast seda, kui Päts oli kodumaale jõudnud, ning ta sõitis 27. novembri õhtul Riiga ja sealt mõne aja pärast Saksamaale ega naasnud enam kunagi Eestisse. ${ }^{59}$

\footnotetext{
Dellingshausen, Kodumaa teenistuses, 208.

Ibid., 209.

Ibid., 239.

RA, ERA.31.1.8, 1. 20: Ajutise valitsuse koosoleku protokoll, 19.11.1918.

Dellingshausen, Kodumaa teenistuses, 210-212,
} 


\section{Põhja-Eesti läheb eestlastele}

Võimu üleminek eestlastele sai alguse 13. novembril, ehkki esimesed sammud selles sihis astuti veidi varem. Need puudutasid korrakaitsestruktuuride ülevõtmist.

Vastavalt valitsuse 11. novembri otsusele asendada Tallinna omakaitse (Bürgerschutzwehr) Eesti kaitseliiduga, kutsus Johan Pitka samal õhtul kokku Omakaitse juhatuse laiendatud koosoleku, millel osalesid juhatuse liikmed ning jaoskondade ja rajoonide ülemad. Kokku tuldi Tallinna Teataja toimetuse ruumides (Suurturg 14). Alustuseks luges Pitka ette akti, milles öeldi, et ajutise valitsuse otsusel likvideeritakse senine omakaitse ja asutatakse Eesti kaitse liit, mille liikmeteks võetakse ainult eestlasi. Seejärel tänas Pitka baltisakslasi senise panustamise eest ning palus neil loovutada relvad ja lahkuda.

Vältimaks sakslaste võimalikke vastuaktsioone suundus Pitka koos kaasvõitlejatega (Peeter Kann, Jaan Lepp, Jaan Naaris, Aleksander Seiman jt) koosoleku lõppedes Mere puiesteele Tallinna laevaühisuse ruumidesse. Seal koostati kaitseliidu manifest, kaitseliidu ülema esimene päevakäsk ning juhtnöörid kaitseliidu kohalike organisatsioonide loomiseks ja tegevuseks. Valminud dokumendid saadeti viivitamatult kulleritega maakondadesse laiali. ${ }^{60}$

Kaitseliidu manifest algas teadaandena: "Saksa võimude ajal asutatud omakaitse on Ajutise Valitsuse käsul likvideeritud. [...] Maa julgeoleku kaitsmise võtab Eesti Kaitse Liit oma peale nii linnas, kui maal”. Järgnevalt kinnitati, et saladuskatte all loodud kaitseliitu on koondunud "arusaajad ja üksteist usaldavad isikud, erakondade vahel vahettegemata, selleks et Eesti rahva peret [...] toore vägivalla, näljasurma ja rahvuslise vägistamise vastu kaitseda." Manifestis nõuti, et valitsema saaks Eesti seaduslik valitsus, milleks tuleb maanõukogul ja tööliste esindajatega täiendatud Ajutisel valitsusel kõige lähemal ajal kutsuda kokku asutav kogu. Hoiatati vägivalla ja korratuste eest ning kutsuti kõiki, "kel kallis meie kodumaa tulevik", kaitseliiduga ühinema. ${ }^{61}$ Päevakäsus kaitseliidule andis kindralmajor Ernst Põdder teada, et võtab Kaitseliidu juhtimise enda kätte ning nimetas ametisse maakondade kaitseliitude ülemad, samuti Tallinna kaitseliidu jaoskonnaülemad ning Tallinna sadama ja raudteejaamade komandandid. ${ }^{62}$

60 Aadu Truuvere, "20 aastat vabatahtlikku kodukaitse tööd”, Kaitse Kodu! nr 20/21 (1938), 667; Richard Tammemägi, "Kaitseliit Eesti riigi rajamisel”, Kaitse Kodu! nr 20/21 (1938), 688; Naber, Johan Pitka, 183-184.

61 RA, ERA.1962.1.150, l. 1: Kaitseliidu manifest, 12.11.1918.

62 RA, ERA.509.1.15, 1. 1: Kaitseliidu päevakäsk nr 1, 11.11.1918. 
Ajutise valitsuse 12. novembri istungil võisid kaitseliidu juhatuse liikmed Rudolf Reimann ja Johan Unt teatada, et Tallinnas on tegevusvalmis 600 kaitseliitlast, kes alustavad samal õhtul patrullimist tänavail ja mehitavad vahipostid tähtsamate objektide juures. ${ }^{63} 14$. novembriks kasvas kaitseliitlaste arv Tallinnas $1400-\mathrm{ni}^{64}$ ning organisatsiooni tegevus laienes pealinnast kaugemale.

Esialgu tegutses kaitseliit ennekõike vabatahtliku abipolitsei rollis, aidates taastataval miilitsal kaitsta sisekorda. Seejuures jäid liidu peamisteks ülesanneteks patrullteenistus suuremates asulastes ning vahiteenistus sõjalistel, riiklikel ja majanduslikel objektidel. Lisaks oli kaitseliit aktiivne mitmetes muudes valdkondades, nagu piirivalve, rannakaitse, merejõudude ja ratsaväe korraldamine jne, aga ka varade ülevõtmine Saksa okupatsioonivõimudelt. Viimane tegevus ei kulgenud just eriti ladusalt ning mõlemad pooled esitasid vastastikku hulgaliselt pretensioone.

Kui kaitseliit sai vabatahtliku organisatsioonina etendada vaid abipolitsei rolli, siis n-ö päris korrakaitse funktsioonid läksid Saksa politseilt üle Eesti miilitsale. Ajutise valitsuse avaistungil langetatud otsust "Politsei asjad peavad omavalitsused ülevõtma" ${ }^{65}$ asus Tallinnas teostama 1917. aastal linna miilitsaülemaks valitud Aleksander Hellat. Hellat on hiljem meenutanud: "Oli harilik novembripäev, päikeseta ja vihmane. Olin teel oma advokaadibüroosse [...], kui kaks meest mind peatasid ja andsid valge ümbriku minule üle. [...] Kirjas oli Ajutise valitsuse lühike ettepanek võtta politseid okupatsioonivõimudelt üle ja asuda ametikohuste täitmisele. Imelik kiri! [...] Minu ilmumisest politseisse ei olnud keegi teatanud, aga mul jäi mulje, nagu oleks oodatud mind seal siiski. Politsei abidirektor Anderson leidis päris korras olevat, et mina tulin vabastama teda ametist. Surusime üksteisele kätt, tema soovis minule kõige paremat, tema lahkus politseist, mina asusin tema laua taha ja politsei oligi üle võetud." ${ }^{\prime 6}$ Seega võttis Hellat juba 11. novembril Tallinna politseivalitsuse asjaajamise ja varad politseimeistri abilt üle. Ööl vastu 12. novembrit kutsus ta kokku endised jaoskonnaülemad ja andis neile käsu hommikuks kõik jaoskonnad üle võtta ${ }^{67}$ Muidugi nõudis miilitsa tegelik rakendumine ülelinnalises ulatuses rohkem aega. Siiski andsid Tallinna ajalehed 16. novembril

63 RA, ERA.31.1.8, 1. 3: Ajutise valitsuse koosoleku protokoll, 12.11.1918.

64 RA, ERA.31.1.8, l. 6: Ajutise valitsuse koosoleku protokoll, 14.11.1918.

65 RA, ERA.31.1.8, 1. 11: Ajutise valitsuse koosoleku protokoll, 11.11.1918.

66 Aleksander Hellat, “Tallinna politsei ülevõtmine okupatsioonivõimudelt”, Eest $i$ Politseileht, 1928, 651-652.

67 Martin Morrison, “Tallinna-Harju prefektuur kümneaastasel arenemisel”, Eesti Politseileht, 1928, 659. 
teada: "Endised politseijaoskonnad on linnas juba üle võetud ja töötavad jälle nimetuse - miilitsajaoskond - all edasi. Ka kevadel ametist tagandatud miilitsionärid on jälle oma ametikohuste täitmisel." ${ }^{\prime \prime 8}$

Seega alustati võimu ülevõtmist korrakaitseorganitest: omakaitse asendati kaitseliiduga ja politsei miilitsaga. Kuid see oli vaid algus ja järjekorras ootasid kõikvõimalikud muud institutsioonid. Ametiasutuste ülevõtmise täpse käigu rekonstrueerimist ei võimalda usaldusväärsete allikmaterjalide nappus. Ajalehtede uudisnupud annavad toimunust vaid katkendliku ja ebatäpse pildi. Ent üht-teist on võimalik siiski teada saada.

Arvestades tõsiseid probleeme tallinlaste varustamisel toiduainetega, oli tarvis kiiresti enda kätte võtta toitlustusküsimuse korraldamine. Tõsi, Tallinna toitlusameti ülevõtmise osas valitseb selgusetus. Mari Raamot on oma mälestustes väitnud, et Jaan Raamot ja Joakim Puhk võtsid toitlusameti üle juba 10. novembril ning pitseerisid kassad ja kapid kinni ${ }^{69}$, kuid siin on tegemist eksitava dateeringuga. Tõsisemalt tuleb suhtuda Saksa võimude 13. novembri teadaandesse, milles väideti, et toitlusamet ("maa varustamise keskkoht") on eestlastele üle antud. Samas kinnitas Jaan Raamot maanõukogu vanematekogu 12. novembri koosolekul, et oli käinud nii toitlusametis kui ka maapealiku jutul, kuid sakslased tõrkusid toitlusametit loovutamast. Ainult toitlusameti kassa õnnestunud kinni panna. ${ }^{70}$ Seega näib, et toitlusameti ülevõtmine algas 12. novembril, kuid ei jõudnud veel lõpule.

13. novembril võtsid ajutise valitsuse volinikud Jüri Jaakson ja Peeter Põld üle parun Tolli majas (Toompuiestee 3) tegutsenud Eestimaa provintsivalitsuse. Kuna provintsivalitsuse ametnike põgenemise tõttu olid kohal vaid kaks Saksa poole esindajat - Eestimaa maapealik (Landeshauptmann) rittmeister von Zahn ja maadirektor (Landesdirektor) vabahärra Robert Karl Fürchtegott von Zedlitz und Neukirch -, teostus üleandmine lihtsalt. Mõlemad pooled allkirjastasid dokumendi, milles konstateeriti, et Eestimaa valitsemine on tänasest päevast läinud provintsivalitsuselt ajutisele valitsusele. Ühtlasi anti üle provintsivalitsuse dokumendid, bürooruumid koos sisustusega ning kassa- ja arveraamatud. Eraldi märgiti, et provintsivalitsuse ametnikud, kes pole Saksa riigi kodanikud, jäävad ajutise valitsuse käsutusse.

\footnotetext{
68 “Tallinna sõnumid”, Tallinna Päevaleht, $\mathrm{nr}$ 127, 16.11.1918.

69 Mari Raamot, Minu mälestused [faksiimile] (Tartu: Kairit Henno, 2009), 217.

70 RA, ERA.78.1.49, lk 130-131: Maanõukogu vanematekogu koosoleku protokoll nr 49, 12.11.1918.
} 
Samal päeval, 13. novembril, võttis Tallinna sadama komandandiks nimetatud kaugsõidukapten Oskar Treilmann üle sadama komandantuuri ning esimesed Eesti vabariigi omandusse läinud ujuvvahendid, sh vahilaeva Lauterbach (hiljem Laine), tulelaevad Revalstein ja Saritšev, jäämurdja-puksiiri Isabella, mootorpaadid Brigitten ja Worms. Ühtlasi nimetas Treilmann oma kolleegi, kaugsõidukapten William Dampfi loodava tuletornide ja meremärkide valitsuse juhatajaks, ülesandega vältida meremärkide purustamist, võtta need sakslastelt üle ja tagada nende toimimine. ${ }^{71}$

14. novembril alustati vanglasüsteemi ülevõtmisega ja veel samal päeval vabastati mitmed poliitvangid, sh 24 . veebruaril Tallinna komandandiks nimetatud Konrad Rotschild. Poliitilistel põhjustel interneeritute vabastamiseks läkitati Peetri (Pääsküla) vangilaagrisse doktor Hans Leesment ja Naissaare vangilaagrisse Jaan Teemant, samas kui leitnant Evald Schiffer saadeti Riiga, nõudmaks sakslastelt Konstantin Pätsi, Aleksander Saare ja August Peeti vabastamist. ${ }^{72}$ Paar päeva hiljem teatasid ajalehed, et Naissaare ja Pääsküla laagrid on likvideeritud - esimesest vabastati 187 ja teisest 490 kinnipeetavat, kuna 74 kriminaalvangi paigutati ümber Tallinna kinnimajadesse. ${ }^{73}$ Päts ja Saar vabastati Albertyni interneeritute laagrist 17. novembril ning Peet Dünamünde (Daugavgrīva) vanglast kas 18. või 19. novembril. ${ }^{74}$

15. novembril võtsid Jüri Jaakson ja Jaak Reichmann ajutise valitsuse esindajatena üle Tallinna ringkonnakohtu ja rahukohtud, koos kõigi varade ja aktidega. Vastaspoolt esindasid ringkonnakohtunik kapten Stephani, rahukohtunikud Carl von Gyldenstube ja T. von Müthel, ringkonnakohtu sekretär Schröter ja kohtutäitur Röse. ${ }^{75}$

Samal päeval alustas endine Tallinna postkontori ülem Hindrek Rikand sideühenduste ülevõtmist, pannes seeläbi aluse teedeministeeriumi posti-, telegraafi- ja telefonivalitsusele. Esialgu õnnestus üle võtta küll vaid postkontorid ja postiagentuurid. Telefonivõrk, mis oli varem

\footnotetext{
71 Arto Oll, Eesti Merevägi Vabadussõjas 1918-1920, doktoritöö (Tallinna Ülikool, 2017), 23, 108.

72 “Tallinna sõnumid”, Tallinna Päevaleht, nr 124, 13.11.1918; "Tallinna sõnumid”, Tallinna Päevaleht, nr 125, 14.11.1918.

73 "Politikavangid", Tallinna Teataja, nr 68, 16.11.1918.

74 Ago Pajur, Konstantin Päts: Poliitiline biograafia. II osa: riigimees (1917-1956) (Tartu: Rahvusarhiiv, 2018), 99; Ferdinand Petersen, Mälestusi ja tähelepanekuid (Tallinn: Tallinna Tehnikaülikool, 2001), 196; August Peet, "Siseministriks Ajutises Valitsuses", Mälestused iseseisvuse võitluspäivilt, II: Vabadussõda 1918-1920 (Tallinn: Eesti ajakirjanikkude liit, 1930), 214.

75 RA, ERA.31.1.3, 1. 15-16: Tallinna ringkonnakohtu ja rahukohtute ülevõtmisakt, 15.11.1918.
} 
kuulunud peamiselt omavalitsustele, mitmesugustele ühingutele ja eraisikutele (riiklikud telefonikeskjaamad töötasid vaid Tallinnas, Tartus ja Narvas), oli Saksa sõjaväevõimude poolt sisuliselt hävitatud (telefonisidet korraldasid Saksa sõjaväeüksused) ning telegraafiühendusi keeldusid sakslased üle andmast. Seetõttu tuli keskenduda postisidele ja selles osas saavutati kiiresti tulemusi. Peamiselt tänu asjaolule, et Hindrek Rikand oli juba sügisel alustanud salajasi ettevalmistustöid, luues isiklikud kontaktid paljude postitöötajatega ja koostades kavasid ja eeskirju tuleviku tarbeks. ${ }^{76}$

16. novembril võeti üle Tallinna tolliamet. ${ }^{77}$ Mõistagi leidus veel hulk asutusi ja ametkondi, mis neil päevil sakslastelt eestlastele läksid, kuid nähtavasti ei ületanud need üksteisele järgnenud ülevõtmised enam ajakirjanduslikku uudiste künnist. Igatahes võib sedastada, et Tallinnas teostus võimu üleminek eestlastele suhteliselt kiiresti ja suuremate tõrgeteta.

Sama väide käib ka kohaliku omavalitsuse kohta, mille taastamine algas 12. novembri keskpäeval, mil raekojale heisati rahvuslik trikoloor ja raekoja saali kogunes 1917. aasta suvel valitud linnavolikogu. Ehkki 101-st volikogu liikmest olid kohal vaid 27 (puudusid kõik enamlased ning mitmed esseerid ja vähemlased), tunnistati koosolek otsustusvõimeliseks. Volikogu andis linnanõunik Aleksander Pallasele volitused asjaajamise üle võtmiseks saksa linnaametilt ning otsustas pidada järgmisel päeval uue koosoleku. 13. novembril võttiski Pallas linnaameti üle ning samal õhtul toimunud volikogu istungil valiti ametisse uus linnavalitsus (linnapea kt Pallas, linnanõunikud Jüri Annusson, Martin Bleimann, Hans Martna, Pullisaar, Anton Uuesson), samuti volikogu uus juhatus (esimees Nikolai Köstner, abiesimees Rudolf Paabo). ${ }^{78}$

Pärast seda, kui kindral Seckendorff tunnustas ajutise valitsuse olemasolu, hakkas valitsuse võim laienema pealinnast kaugemale. Valitsuse 13. novembri hommikusel istungil otsustati "E.A.V. volinikuks Põhja-Eestimaal määrata adv. K. Parts, kuni tema ametisse astumiseni J. Jaakson. Lõuna-Eestimaal E.A.V. volinikuks adv. Ostrat, ehk kui tema vastu ei võta, siis keegi asetäitja K. Partsi äranägemise järel". ${ }^{79}$ Mingil põhjusel realiseerus valitsuse otsus vaid osaliselt, sest siseministri kohuseid täitnud Juhan

\footnotetext{
76 “Tallinna sõnumid”, Tallinna Päevaleht, nr 127, 16.11.1918; “20 aasta eest: Kuidas loodi esimesed eesti postiasutused", Postisarv: posti-, telegraafi-, telefoni- ja raadioteenijate ajakiri, nr 11 (1938), 194-195; Hindrek Rikand, "Põrandaalune ametkonnaloomine", Postisarv: posti-, telegraafi-, telefoni- ja raadioteenijate ajakiri, nr 11 (1938), 195-196.

77 RA, ERA.20.1.11, 1. 19: Tallinna tolliameti ülevõtmisakt, 16.11.1918.

78 “Tallinna linnavolikogu koosolek", Tallinna Päevaleht, nr 124, 13.11.1918; “Tallinna linnavolikogu koosolek", Tallinna Päevaleht, nr 125, 14.11.1918.

79 RA, ERA.31.1.8, 1. 5: Ajutise valitsuse koosoleku protokoll, 13.11.1918.
} 
Kukk määras samal päeval Jüri Jaaksoni ajutise valitsuse ülemvolinikuks Põhja-Eestisse ja Kaarel Partsi samasse ametisse Lõuna-Eestisse.$^{80}$ Mingil ajahetkel sai ülemvoliniku õigused Lõuna-Eestis lisaks Partsile Tartu proviisor Heinrich Luht.

13. novembril sai alguse ka valitsuse volinike (usaldusmeeste) nimetamine maakondadesse ja linnadesse. Muuhulgas määrati usaldusmeheks Võrru advokaat Martin Taevere ${ }^{81}$ ja Narva advokaat Tõnis Kalbus. Viimasele tehti ülesandeks kutsuda ellu Narva ajutine linnavalitsus ja Alutagusemaa omavalitsus. ${ }^{82}$ Volinike kohustused polnud teadaolevalt üheski ametlikus dokumendis fikseeritud, kuid nähtavasti olid nad mõeldud täitma 1917. aastal loodud maakonnakomissaride ülesandeid. Öeldi ju ka valitsuse 11. novembri pöördumises rahva poole, et kohalikud omavalitsused peavad tegusema juhatuste järel, mida ajutise valitsuse volinikud kohtadel annavad. ${ }^{83}$

13. novembriga on dateeritud ka siseministri kohusetäitja ringkirjaline korraldus linnapeadele ja maakonnavalitsuste esimeestele. Neil kästi alustada viivitamatult tegevust, kutsuda kokku kohalik esinduskogu (linnavolikogu või maakonnanõukogu) ja moodustada korrakaitse tagamiseks miilits. $^{84}$

Need korraldused leidsid Põhja-Eesti makondades kiiret täitmist. Virumaal võttis valitsuse usaldusmees Mihkel Juhkam 14. novembril üle kohaliku kreisipealiku asjaajamise ja nimetas endise maakonnakomissari Tõnis Kalbuse ajutiseks kohtunikuks Rakverre. Viimane kandis veel samal päeval kohtuministrile ette: “Täna võtsin kohtud, krepostijaoskonna ja vangimajad üle. Vangis istuvad praegu umbes 150 meest, osalt otsuste järele, osalt eeluurimise all. Arvan, et suurema osa väiksemaid süüdlasi otsekohe vabastan. Palun juhtnöörisi saata, mis suurema süüdlastega tegema pean, kes alles eeluurimise all on." Rakvere saksa linnavalitsus loovutas võimu eestlastele 15 . novembril. ${ }^{85}$

14. novembril teatasid võimu ülevõtmisest ka Järva maakonnavalitsuse esimees Viktor Tomberg ja valitsuse usaldusmees Narvas Arnold Schulbach. Viimane raporteeris napisõnaliselt: "Varustusasi ülevõetud. Salapolitsei kinnipitseritud. Politseisse komandant sisse pandud. Kaitseliit elule

80 RA, ERA.14.1.20, 1. 11: Siseministri telegramm (ringkirjaline), 13.11.1918.

81 RA, ERA.14.1.24, 1. 16: Siseminister Martin Taeverele, dat-mata.

82 RA, ERA.14.1.24, 1. 1: Siseminister Tõnis Kalbusele, 13.11.1918.

83 "Eesti Ajutine Valitsus Eestimaa rahvastele, 11.11.1918", Riigi Teataja, 1 (1918), 2-3.

84 RA, ERA.14.1.20, 1. 5-10: Siseministri ringkiri, 13.11.1918.

85 "Rakverest", Postimees, nr 220, 20.11.1918; RA, ERA.76.1.197, 1. 1: Tõnis Kalbus kohtuministrile, 14.11.1918. 
kutsutud. Linna volikogu laupäevaks kokku kutsutud. Posti ja telegrahvi ülevõtmiseks eelkorraldused tehtud. Täielik kord.”86

Harju maakonnavalitsuse esimees Johannes Reinthal jõudis ametliku aruande kirjutamiseni 16. novembril ja jäi üldsõnaliseks: "Täites ettekirjutust 13. nov. s.a. N 6, on mul au ette kanda, et olen oma ametikohustuste täitmisele asunud ja maakonna asutused Pagari uul. N 1 üle võtnud. Maakonna miilits on elusse kutsutud ja vallavalitsuste töökorraldamine on käsil." ${ }^{87}$

Valitsuse volinik Haapsalus Eduard Alver meenutas kakskümmend aastat hiljem, kuidas ta 14. novembril kaitseliidu toel sakslasest kreisipealikult asjaajamise Läänemaal üle võttis, rõhutades: "See toiming tuli sakslasile niivõrd üllatuslikult ja kiiresti, et sellest ei suudetud toibuda. Kolmandal päeval saabus Tallinnast Haapsalu kreishauptmanni nimele telegramm, mis minu kätte toodi, et ta mingil tingimusel võimu eestlasile üle ei annaks. Kuid oli juba hilja - kreisiameti hoonel lehvis juba kolmandat päeva Eesti Vabariigi lipp ja relvastatud kaitseliitlased pidasid kõikjal korda." 88

\section{Takerdumine Lõuna-Eestis}

Kui Põhja-Eestis toimus võimu loovutamine eestlastele suhteliselt kiiresti ja ladusalt, siis 6o. armeekorpuse haldusalas see protsess takerdus. Nähtavasti oli põhjuseks kindralkomando suurem enesekindlus ja jäikus. Erinevalt Seckendorffist, kes jäi Tallinnas Saksa sõjaväelaste revolutsiooniliste meeleolude ja eestlaste rahulolematuse vahele lõksu, võis Tartus resideerunud kindral Estorff tunda end märksa kindlamalt. Tartus valitses jätkuvalt rahu ja kord ning ainsateks revolutsiooni ilminguteks jäid kohaliku soldatite nõukogu moodustamine ja mõne sinimustvalge lipu heiskamine. Pealegi asus rahustavalt lähedal okupatsioonivõimude tähtsaim kants Riia, kus resideerusid nii 8. armee juhatus kui ka ühendatud Balti hertsogiriigi regentnõukogu. Mõistagi ei tahtnud kumbki nimetatutest eestlaste taotlustest kuuldagi ning meelestas vastavalt ka kindral Estorffi.

Tartusse jõudsid teated Tallinna sündmustest 12. novembril, levides kiiresti suust suhu ja tekitades eestlaste seas üldist elevust. Värskete uudiste jahil kogunes hulk inimesi Postimehe ja Maalehe toimetuste juurde. Mõlemale hoonele heisati sinimustvalge lipp ja toimetused teatasid Saksa ajakirjandusbüroole (Pressestelle), et ei saada enam ajalehti tsenseerimiseks.

86 RA, ERA.14.1.46, 1. 38: Järva maakonnavalitsuse esimees siseministrile, 14.11.1918; RA, ERA.31.1.3, 1. 4: Usaldusmees Narvas Ajutisele valitsusele, 14.11.1918.

87 RA, ERA.14.1.46, 1. 43: Harju maakonnavalitsuse esimees siseministrile, 16.11.1918.

88 Eduard Alver, “Eesti Kaitseliit Vabadussõja päevil”, Kaitse Kodu! nr 2o/21 (1938), 681. 
Seepeale ilmus kohale ajakirjandusbüroo ülem leitnant Müller koos sõduritega ja käskis trükimasinad seisma panna. Ajakirjanike protestide peale ta siiski leebus, lubas trükkimise lõpetada ja ajalehed müüki saata, ent hoiatas, et teeb ettekande kõrgematele ülematele. Samal õhtul marssisid mõlema ajalehe ruumidesse Saksa sõdurid. Neid juhtinud ohvitserid nõudsid, et trükikojad suletaks ja ekspeditsioonist ajalehti välja ei saadetaks. Kõikidesse ruumidesse seati relvastatud vahipostid.

13. novembri hommikul jätkasid Postimehe ja Maaliidu toimetajad Adam Bachmann ja Georg Vestel läbirääkimisi leitnant Mülleriga, kes oli saanud Riiast uusi suuniseid. Müller kinnitas, et täielik sõnavabadus pole veel võimalik ning kirjutised, mis puudutavad Eestis viibivaid Saksa vägesid, vajavad jätkuvalt tsenseerimist. Kõnelused lõppesid tulemusteta. Sel päeval jõudis lugejateni vaid Postimees, sest Maaliidu toimetuses teostus põhjalik läbiotsimine ja toimetaja Vestel arreteeriti, süüdistatuna saksavastaste meeleolude õhutamises. 14. novembril vahistati ka Bachmann ja peatati Postimehe ilmumine.

Säärases olukorras leidsid ajakirjanikud ootamatu liitlase Tartu Saksa soldatite nõukogu näol. Esialgu kahtlustasid küll sõduridki eesti ajalehti saksavastasuses, kuid tähtsustasid oma revolutsioonivaimustuses ka sõnavabadust. 15. novembril sündis kokkulepe, millega soldatite nõukogu tagas eesti ajalehtede tsensuurivaba ilmumise ning toimetused kohustusid mitte avaldama Saksa sõjaväe julgeolekut või au kahjustavaid kirjutisi. Ühtlasi lubasid ajakirjanikud suhtuda mõistvalt vajadusse hankida Eestist toiduaineid Saksa sõdurite tarvis, samuti vajadusse jätkata veel mõnda aega senise haldusaparaadi tegevust. Veel samal õhtul vabastatigi Vestel ja Bachmann arestist ning alates 16. novembrist ilmusid Maaliit ja Postimees tsensuurivabalt. ${ }^{89}$

Kuid saavutatud kokkulepe puudutas üksnes ajakirjandust ning haldusasutusi keeldusid sakslased jätkuvalt eestlastele loovutamast. Tartu maakonnavalitsuse esimees Johan Jans oli saatnud 12. novembril valdadesse ringkirja, milles nõudis, et demokraatlikult valitud vallavalitsused ja -nõukogud astuksid viivitamatult tegevusse, kutsuksid ellu korrakaitse struktuurid ja peataksid sakslaste varustamise toiduainetega. ${ }^{90}$ Ringkiri ei andnud tulemusi. 14. novembril saatis siseminister Juhan Kukk Tartusse volituse, mis kohustas Kaarel Partsi ja Heinrich Luhti pidama läbirääkimisi ja sõlmima kokkuleppeid okupatsioonijõudude esindajatega võimu

89 Postimees, nr 213-217, 12.-13. ja 16.-17.11.1918; Maaliit, nr 168, 16.11.1918; "Ülevaade Tartu sündmustest", Tallinna Teataja, nr 69, 18.11.1918.

90 "Kõigile Tartumaa vallavalitsustele", Postimees, nr 213, 12.11.1918. 
üleandmiseks kogu Põhja-Liivimaal, st Tartu, Võru, Viljandi, Pärnu ja Petseri maakondades. ${ }^{91}$ Esimese vastava katse tegi Heinrich Luht 16 . novembril, väisates koos Tartu linnapea Jaan Kriisaga bürgermeistrit ja koos maakonnavalitsuse esimehe Jansiga kreisipealikut. Bürgermeister Egmont Brock kinnitas, et kuna ta allub linnapealikule, siis puuduvad tal volitused läbirääkimisteks. Volituste puudumisega vabandas end ka kreisipealik..$^{92}$

Mujal Lõuna-Eestis polnud olukord parem. Viljandi makonnavalitsuse sekretär Andres Loorits ja linnapea Gustav Talts said samuti Tallinnast korralduse asjaajamine sakslastelt üle võtta, kuid põrkusid jäigale vastuseisule. Kreisipealik kapten Winterfeldt teatas, et "tema senikaua, kui oma seniselt ülemuselt [...] otsekohest käsku ei saa, midagi üle ei anna, mingisuguseid koosolekuid ega korraldusi teha ei lase". Linnapea Otto von Engelhardt deklareeris, et tema "linnavalitsuse asjaajamist käest ei anna ega linnavalitsuse ruumidesse [...] "endist revolutsioonilist" linnavolikogu kokku kutsuda ei lase". Sakslaste vastuseisust hoolimata astus 17. novembril kokku Viljandi maakonnanõukogu ja kinnitas ametisse maakonnavalitsuse, mis omakorda saatis laiali ringkirja, käskides vallanõukogudel ja -valitsustel kolme päeva jooksul võim üle võtta. ${ }^{93}$ Kuid reaalne võim jäi endiselt sakslaste kätte ning veel 19. novembril teatati Viljandist siseministrile: "ikka veel tõrgutakse maakonna valitsemist üleandmist." ${ }^{94}$

Pärnus tegid maakonnanõukogu aseesimees Johannes Hansen ja linnapea Jaan Leesment 15. novembril Saksa 19. maakaitseväediviisi juhatusele ettepaneku võim maakonnas ja linnas Eesti omavalitsustele üle anda. Sakslased keeldusid seda võimalust isegi arutamast, viidates, nagu mujalgi, vastavate käskude puudumisele. Päev hiljem käisid linnapea Leesment, abilinnapea Jaan Timusk ja maakonnavalitsuse esimees Theodor Pool sama jutuga Pärnu kreisipealiku von der Goltzi juures, ent said samasuguse vastuse osaliseks. 19. novembril, st nädal pärast ajutise valitsuse kokku astumist, ilmunud Postimehe Pärnu "saba" andis teada: "Seisukord Pärnus ei ole viimastel päevadel muutunud. Kohalikud sõja-võimud, kelle seljataga kahtlemata meie Balti purutagurlised sakslased [...] seisavad, on kõik rattad ja rahad liikuma pannud, et aga Eesti Ajutisele Valitsusele vastu töötada nii kaua kui see iganes võimalik." Nii kreisipealik kui ka Pärnu soldatite nõukogu vastasid eitavalt kaitseliidu taotlusele relvade saamiseks. Kohatist

91 RA, ERA.14.1.24, 1. 9: Volikiri Kaarel Partsile ja Heinrich Luhtile, 14.11.1918.

92 "Läbirääkimised praeguse maakonna ja linnavalitsusega", Postimees, nr 216, 16.11.1918.

93 "Viljandi Maakonna Valitsuse tegevus", Sakala, nr 3, 19.11.1918; "Viljandi maakonnavalitsuse ringkiri $\mathrm{nr}$ 1, 18.11.1918", Eesti Vabariigi sisepoliitika 1918-1920: dokumentide kogumik, Ad fontes 5 (Tallinn: Rahvusarhiiv, 1999), 245.

94 RA, ERA.14.1.46, 1. 49: Viljandi maakonnavalitsuselt siseministrile, 19.11.1918. 
edu saavutati vaid maal, kus mõned aktiivsemad vallavalitsused sakslaste poolt ametisse seatud eestseisjad kõrvale tõrjusid ja tööd alustasid. ${ }^{95}$

Võrus novembrikuu keskpaiku valitsenud olusid iseloomustas ajakirjanik Johann Semm (Semmiste): "Sakslane on valitsemas endiselt igal pool. Eesti Vabariigi Valitsusest on vahest näha kohapäälseid esindajaid jooksmas ühest asutisest teise voli- ja käskkirjad ülevõtmiste kohta peos, milliseid käskkirju okupatsioonivõimud ei täida. Ainult tühja ja rikutud telegraafiaparaadiga postijaoskonna saavad kätte." 96

Kui üldjuhul jäid eestlased vaoshoituteks, tuletades oma nõudmisi küll Saksa halduritele aeg-ajalt meelde, kuid asudes seejärel taas äraootavale positsioonile, siis tartlased võtsid käredama tooni. 18. novembril teatas Postimees, et Tartu eesti poliitiliste erakondade keskbüroo ja tööliste ametiühingud on ühiselt otsustanud korraldada 20. novembril suure meeleavalduse, nõudmaks saksa linnavalitsuse ja tema asutuste viivitamatut loovutamist eestlastele. ${ }^{97}$

Järgmisel päeval avaldati eelseisva meeleavalduse kava. 20. novembri hommikul kell 10 tuli lõpetada töö kõigis vabrikutes, töökodades, ärides, asutustes, koolides ja mujal. Kell 10:30 pidid töölisühingute, haritlaste ja üliópilaste organisatsioonide ning rahvuslike seltside ja ühenduste liikmed, samuti kooliõpilased ja ülejäänud linnarahvas kogunema Uueturu tänavale. Sealt kavatseti marssida ühiselt Raekoja ette, et anda seal Saksa linnaametile ja Saksa soldatite nõukogule üle korraldava komitee poolt kokku seatud nõudmised. Muuhulgas nõuti: taastada kodanike põhiõigused, vabastada poliitvangid, lõpetada rekvisitsioonid ning toiduainete ja muude varade väljavedu, anda linna- ja maakonnaasutused üle demokraatlikult valitud omavalitsustele, mitte takistada ajutise valitsuse korralduste täitmist. Kõike seda tuli teha "otsekohe" ja "viibimata", sest ajalehe sõnul: "Meie oleme kannatusega oodanud, kõigist avalikkudest väljaastumistest tagasi hoidnud. Nüüd on meie rahulik kannatus otsas." 98

Meeleavaldusega ähvardamine tekitas sakslastes ärevust. 18. novembril jõudis Postimehe toimetusse bürgermeister Egmont Brocki ja linnanõunike kiri, milles nad püüdsid põhjendada viivitamist linnavalitsuse üleandmisega. Nemad olla juba 16. novembril andud linnapealikule palve end ametist vabastada, kuid kuna linna juhtimine on täielikult linnapealiku käes,

95 Postimees: Pärnu väljaanne, nr 195, 19.11.1918; Ago Pajur, Aldur Vunk, Rahvusriigi sünd Pärnumaal (1917-1919) (Pärnu muuseum, 2008), 72-73.

96 J. S. Panius, Sõja ja revolutsiooni keerises: meeleolulisi mälestusi 1914.-1920. a. (Võru, 1933), 176.

97 "Rahulik meeleavaldus" Postimees, nr 218, 18.11.1918.

98 “Välja üleüldisele meeleavaldusele!”, Postimees, $\mathrm{nr}$ 219, 19.11.1918. 


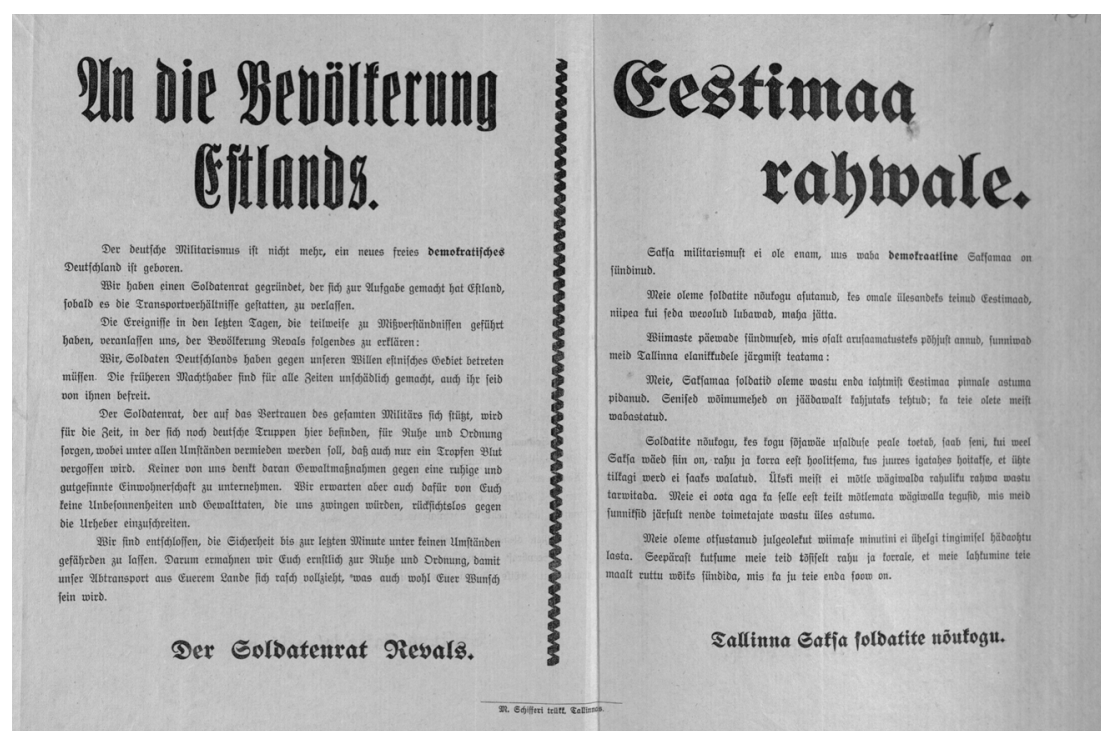

Joonis 2. Tallinna Saksa soldatite nõukogu pöördumine Eestimaa rahva poole (RA, ERA.534.1.29, 1. 167).

siis polevat neil võimalik linnavalitsust üle anda.$^{99}$ Nähtavasti vabandus ei mõjunud, sest järgmisel õhtul ilmusid Saksa linnavalitsuse liikmed endise linnapea Jaan Kriisa jutule ning teatasid, et on valmis ükskõik mis ajal linna asjaajamise ja linna varad Eesti linnavalitsusele üle andma. Enamgi veel, kui linnapealik peaks pü̈̈dma üleandmist takistada, panevad nemad ameti viivitamatult maha ja lahkuvad ametist. Seejärel lepiti Kriisaga kokku, et linnavalitsuse üleandmine algab 20. novembri hommikul kell 9. Kriisa lubas omalt poolt astuda samme meelevalduse ära jätmiseks. Paraku mõjus surveavaldus üksnes linnavõimudele. Seevastu Tartu soldatite nõukogu kleepis 19. novembri õhtul tänavnurkadele teadaanded, milles alustuseks deklareeriti, et Saksa sõdurid ei soovi sekkuda kohalikku poliitikasse, kuid kohe seejärel hoiatati kavandatavas meeleavalduses osalemise eest, kuna väljaastumine olevat sihitud demokraatliku Saksamaa valitsuse vastu ning ohustavat avalikku korda, mistõttu võib osutuda demonstratsiooni käiku sekkumine vältimatuks. ${ }^{100}$ Kahtlemata oli tegemist ähvardusega.

99 Postimees, nr 219, 19.11.1918.

100 "Kohalikud teated", Postimees, nr 220, 20.11.1918. 


\section{"Riia rahu"}

Kuna Lõuna-Eestis oli võimu üleminek takerdunud ja ühise keele leidmine Saksa sõjaväelastega osutus peaaegu võimatuks, siis ootasid eestlased pikisilmi uuenenud Saksamaa esindaja saabumist. Esiotsa arvati Tallinnas, et esindajaks saab Saksamaa sotsiaaldemokraatliku partei riigipäevasaadik Albert Südekum ning nii otsustas ajutine valitsus juba 13. novembril: "Põld, Poska ja Konik Riiga Südekumi juure saata ülevõtmiste asjus läbirääkima." 101

Südekumi siiski Riiga ei läkitatud ja tema asemel nimetati 14. novembril Saksa riigi peavolinikuks Baltimaades (Generalbevollmächtigte des Reichs für die Baltischen Lände) August Winnig - ametiühingutegelane ja sotsiaaldemokraadist parlamendisaadik. Winnigi kasuks rääkis tõsiasi, et ta oli viimase aasta jooksul kahel korral Venemaa endisi Läänemere provintse väisanud ja tundis mõningal määral kohalikke olusid. Oktoobris 1918 oli ta muuhulgas kohtunud ka eestlastega, peamiselt sotsiaaldemokraatidega, kellele temast küll head muljet ei jäänud. Tartu maakonnanõukogu esimehe Jansi arvates oli Winnig huvitatud vaid Saksa mõju säilimisest Baltimaades, koloniseerimisvõimaluste avamisest saksa talurahvale ja baltisakslaste privileegide kaitsmisest. ${ }^{102}$

16. novembril sai ajutine valitsus Riiast telegrammi, milles Winnig andis teada enda ametisse määramisest, avaldas soovi luua kontakt Eesti valitsusega ja palus saata valitsuse esindajad läbirääkimistele. ${ }^{103} 17$. novembril otsustati läkitada Riiga delegatsioon koosseisus: teedeminister Ferdinand Peterson, endine päästekomitee liige Konstantin Konik, maanõukogu liige Ado Birk, Tartu maakonnavalitsuse esimees Johan Jans, Tartu linnapea Jaan Kriisa ja riigivaranduste ülevõtmise komisjoni esimees Voldemar Puhk. Tegelikult jäi Tartu linnapea Kriisa kodulinna ja teda asendas 16. novembri õhtul koos Johan Jansiga Riiga sõitnud ajutise valitsuse peavolinik Lõuna-Eestis Heinrich Luht.

Luht ja Jans alustasid läbirääkimisi Winnigiga 17. novembril ja järgmisel päeval ühinesid nendega saatkonna ülejäänud liikmed. Kõnelused leidsid aset hotellis Bellevue, kus Winnig peatus. Kuna kokkuleppe tekst pandi kirja vastavalt kõneluste edenemisele punkt-punkti haaval, siis sisaldab lepingu originaal rohkesti mahakriipsutusi ja parandusi-täiendusi. Leping koostati saksakeelsena ja kahes eksemplaris ning kirjutati hariliku pliiatsiga

101 RA, ERA.31.1.8, 1. 5: Ajutise valitsuse koosoleku protokoll, 13.11.1918.

102 Johan Jans, Mälestusi ja vaatlusi ([2. trükk] Tartu: Ilmamaa, 2008), 341-345.

103 RA, ERA.14.1.24, 1. 18: August Winnig ajutisele valitsusele, 16.11.1918. 
valgetele paberilehtedele. Ei eestlastel ega sakslastel olnud ühtegi pitsatit, mistõttu piirduti kokkuleppe kinnitamisel läbirääkijate allkirjadega.

Läbirääkimistel valitsenud onhkkonda ja August Winnigi suhtumist eestlastesse on iseloomustatud erinevalt. Ferdinand Petersoni sõnul oli Winnig "sõbralik, lihtne käitumises ja vastutulelik, kuid küllalt pedantne Saksamaa huvide kaitsmisel". ${ }^{104}$ Konstantin Konik väitis, et Winnig "ei suutnud midagi otsustada iseseisvalt ja paistis mängukannina Saksa sõjavõimude käes" ${ }^{105}$ Kõige kriitilisem oli Johan Jans, kelle vastumeelsus pärines oktoobrikuisest kohtumisest. Kahe marksisti vastasseis paisus Riias sedavõrd suureks, et Jans viskas õhku otseselt solvava küsimuse: kas Winnig üldse ongi sotsiaaldemokraat? ${ }^{106}$ Võimalik, et just nende teravuste tõttu sõitis Jans 18. novembri õhtul Tartusse ega osalenud lepingu allkirjastamisel.

Kõnelused ei osutunud hõlpsateks. Esimesena kerkis küsimus, kelle vahel leping sõlmitakse. Winnig kartis, et kui lepingu ühe poolena mainitakse Eesti ajutise valitsuse esindajaid, võidaks seda tõlgendada kui Eesti vabariigi ametlikku tunnustamist Saksamaa poolt, milleks tal puudusid volitused. Laveerides püüdis ta tugineda kahele argumendile: esiteks olevat Brest-Litovski rahulepingu tühistamise läbi Eesti muutunud taas Venemaa osaks ning teiseks keelavat Compiègne'i vaherahulepe Saksamaal tunnustamast endise Vene impeeriumi äärealadel moodustunud uusi riike. Eestlased seevastu rõhusid rahvaste enesemääramisõiguse põhimõttele ning asjaolule, et Briti, Prantsuse ja Itaalia valitsused olid tunnustanud Eesti vabariiki de facto. Pärast pikemaid vaidlusi saatis Winnig Berliini telegrammi, milles tegi ettepaneku tunnustada Eesti valitsust ajutiselt.

Teine küsimustering seondus samuti Eesti valitsuse staatusega, sest kuniks ajutine valitsus polnud tunnustatud, ei saanud talle ka kõrgema riigivõimu funktsioone üle anda. Eestlased soovitasid loovutada need kohalikele omavalitsustele, kuid Winnig leidis, et omavalitsustel puudub pädevus üleriigiliste küsimuste lahendamiseks. Sellest tulenevalt tegi ta omalt poolt ettepaneku anda võim üle pariteedi alusel moodustatud Eesti-Saksa komisjonidele. Mõistagi ei saanud eestlased taolise ettepanekuga soostuda. Lõplikult langes see päevakorrast pärast seda, kui selgus, et Berliin on põhimõtteliselt nõus ajutist valitsust tunnustama.

Keerukaks probleemiks kujunesid ka võimu loovutamise tähtajad. Eestlased olid huvitatud võimalikult kiirest tegutsemisest, Winnig aga pidas eeskätt silmas Saksa vägede väljaviimise tempot, püüdes säilitada Saksa

104 Petersen, Mälestusi ja tähelepanekuid, 194.

105 Konik, "Mälestuste katkendid", 27.

106 Jans, Mälestusi ja vaatlusi, 353. 
asutuste kontrollifunktsioone kuni evakuatsiooni lõpuni. Pärast pikki kauplemisi soostus Winnig lahendusega, et sakslaste kontrolli alla jäävad vaid raudtee- ja sideühendused.

Põgusalt puudutati Eesti sõjalise kaitsmise võimalusi. Eestlasi huvitas kaks põhiküsimust: esiteks, kas sakslased on valmis osalema Eesti idapiiride kaitsel punaarmee võimaliku sissetungi korral kuniks Eesti jõuab ise piisava riigikaitse korraldada, ning teiseks, kas sakslased on valmis loovutama loodavate Eesti kaitsejõudude jaoks sõjavarustust, eeskätt neid relvi, mis kevadel Eesti sõjaväelt ära võeti. Kummagi küsimuse osas kokkulepet ei saavutatud. ${ }^{107}$

19. novembri õhtuks jõuti kõnelustega ühele poole, dokumendile kirjutati alla ja Eesti saatkond asus õhtuse rongiga koduteele. 20. novembri pärastlõunal saabuti Tallinna ning veel samal õhtul kiitis ajutine valitsus Riia lepingu heaks. ${ }^{108}$ Valitsuse heakskiiduga piirdutigi ja maanõukogu 23. novembri koosolekul mainiti kokkulepet vaid möödaminnes - Ado Birk tõdes, et "Riias läbirääkimiste juures kaitse asjus midagi kätte ei saadud". ${ }^{109}$

Winnigi hotellitoas allkirjastatud dokument oli üpris lühike, koosnedes vaid üheksast punktist, ning kandis pretensioonitut pealkirja "Kokkulepe" (Vereinbarung). Riigi Teataja esiknumbris sai see nimeks "Üleandmise leping" ning Eduard Laamani eeskujul on seda hiljem nimetatud "Riia rahuks", ehkki õiguslikult polnud tegemist rahulepinguga. Küll aga võib selles näha nii Eesti vabariigi esimest välislepingut kui ka Saksamaa valitsuse de facto tunnustust Eesti iseseisvusele.

Kokkuleppes sätestati:

1) kõrgemat riigivõimu Eesti territooriumil teostab Eesti maanõukogu ees vastutust kandev ajutine valitsus;

2) kogu valitsusvõim läheb alates 21 . novembrist üle ajutise valitsuse asutuste kätte, kes võtavad üle ka kõik laod, tagavarad, bürood, inventari ja kassaseisud (v.a Saksa sõjaväe varad);

3) Eestis viibivatel Saksa vägedel pole õigust sekkuda valitsemisasjadesse; sõjaväelaste majutamise ja toitlustamise eest hoolitseb valitsus koostöös Saksa sõjaväeasutustega; valitsust teavitatakse jooksvalt kõigist vägede

\footnotetext{
107 Laaman, Eesti iseseisvuse sünd, 352-353; Küllo Arjakas, Konstantin Konik: unustatud suurmees (Tallinn: Eesti Päevaleht, 2008), 142-145; Petersen, Mälestusi ja tähelepanekuid, 194-199; Jans, Mälestusi ja vaatlusi, 351-357.

108 Pajur, Konstantin Päts, II, 101; RA, ERA.31.1.8, 1. 24-25: Ajutise Valitsuse koosoleku protokoll, 20.11.1918.

109 "Maanõukogu kinnise koosoleku protokoll nr 62a, 23.11.1918”, Maanõukogu protokollid 1917-1918 (Tallinn, 1935), 305.
} 
väljaviimisega seotud sammudest ning vägede lahkumisel antakse üle sõjaväe poolt kasutamist leidnud sisseseaded;

4) valitsus võtab üle postiühendused, kuid telegraaf ja telefon jäävad ajutiselt sõjaväevõimude kontrolli alla, kes võimaldavad nende kasutamist tsiviilelanikele;

5) kuni raudteede ülevõtmiseni saadab valitsus sõjaväe raudteedirektsiooni, selle asutustesse ja raudteejaamadesse oma komissarid;

6) materiaalsete väärtuste väljavedu allutatakse valitsusasutuste kontrollile (v.a Saksa sõjaväe varad);

7) Eesti arvatakse välja Ober-Ost'i tollipiirkonnast;

8) Tartu ülikool antakse üle hiljemalt käesoleva semestri lõpus;

9) mõlemad pooled soovivad korraldada edaspidiseid suhteid kõige paremas läbisaamises. ${ }^{110}$

Ehkki August Winnig oli läbirääkimistel eestlastele vaid osaliselt vastu tulnud, pidas Saksamaa keskvõim sedagi liiaks ja asus lepingut oma kasuks tõlgendama. 22. novembril sai ajutine valitsus Winnigi vahendusel telegrammi, mis tutvustas Saksa valitsuse seisukohti. Telegrammis rõhutati, et Eesti valitsus ja Saksa kindralkomando on üheõiguslikud, tegutsevad võrdsetel alustel teineteise kõrval ega allu teineteisele. Telegraafi- ja telefoniühenduste kasutamine tsiviilelanike poolt seati sõltuvusse Saksa sõjaväe nõusolekust. Lubati küll kaasabi avalike kõnepunktide sisseseadmisel, kuid nende punktide ühendamine liinivõrguga vajas taas sõjaväe nõusolekut. Ajutise valitsuse haldusse läinud postiasutused pidid piirduma üksnes tsiviilelanike saadetiste menetlemisega, samas kui Saksa asutuste ja Saksa sõjaväelaste saadetised käisid jätkuvalt läbi Saksa postiameti. Nõuti, et ajutine valitsus varustaks Saksa sõjaväge kõige hädavajalikuga endises mahus, ehkki ei välistatud sõjaväeladudes leidunud tagavarade kasutamise võimalust. Reeglina kuulusid taolised varad siiski evakueerimisele ning vaid erandkorras võis mingil põhjusel sõjaväest maha jäävat kraami müüa Eesti valitsusele. Lõpetuseks deklareeriti, et Tallinnas asuvaid toorainevarusid ei tohi ajutisele valitsusele üle anda, kuna Saksamaal valitseb nende järele tungiv tarvidus (tekstiilikaubad väideti olevat Saksa sõjaväe vara). Saksamaale viidava tooraine eest pakuti kompensatsioonina kas ersatsõlisid ja karbiiti gaasilampide jaoks või soola ja suhkrut. Seejuures ei unustatud ähvarada: "Peaks äravedu takistada katsutama, siis oleks

110 “Üleandmise leping, 19.11.1918", Riigi Teataja, nr 1, 1918, 7; RA, ERA.31.1.3, 1. 6-7: Vereinbarung, 19.11.1918. 
kõige tõsisem konflikt mööda peasemata."111 Seega tõlgendas Berliin Riias saavutatud kokkulepet moel, mis piiras eestlaste tegevusvabadust võimalikult suures ulatuses.

\section{Ülevõtmised jätkuvad}

Kuna Põhja-Eestis oli läinud tegelik võim eestlastele enne Riia lepingu sõlmimist, siis kujunes kokkulepe olulisemaks Lõuna-Eesti jaoks, kus sakslased jätkuvalt peremehetsesid. Nüüd pidid nad siiski järele andma, ehkki vastu tahtmist ja venitamisi. Lepingu kohaselt pidanuks kogu võim kuuluma alates 21. novembrist eestlastele, ent nii kiiresti see ei toimunud.

22. novembril ilmunud Sakala andis lugejaile teada, et Viljandis pole valitsusasutuste ülevõtmine ikka veel alanud, kuna sakslased ootavat Riiast mingisuguseid ettekirjutusi. Ainsa erandina tehti 21. novembril algust postiameti ülevõtmisega. ${ }^{112}$ Ajalehe järgmine number oli pisut optimistlikum, teatades, et 23. novembril läksid eestlaste kätte nii linnavalitsus kui ka politsei. Linnavalitsuse puhul lisati: ““Üle anti” tühi linna kassa, võlad, [...] Saksa sõjalaenu paberid, viletsas seisukorras olev toitlusasi jne." 25. novembril võeti üle linnavalitsuse ülalpidamisel olnud koolid ning tehti algust maavalitsuse ülevõtmisega. ${ }^{113}$

Ka Pärnus toimetasid sakslased härgamisi. 21. novembril tunnistas Pärnu kreisipealik, et on saanud Riiast üldsõnalise korralduse ametiasutused eestlastele üle anda, kuid kuna puuduvad täpsed juhtnöörid, siis pole võimalik käsku täita. Päev hiljem ta siiski taandus ning Pärnus ilmunud Postimehe lisaleht rõõmustas: "Viimaks ometi on ka Pärnu kants ennast alla annud!" 114 Tegelik võimu üleandmine sai teoks põhiliselt 23.-24. novembril, mil eestlased võtsid üle nii linna- kui ka maakonnavalitsuse, samuti politseiasutused, posti- ja telegraafikontori, elektrijaama, sadama, haigla, vangimaja jne. Kuid veel 25. novembrikski ei saadud sakslastelt kätte ei kohtuid (v.a politseikohus) ega koole. ${ }^{115}$

Kohtusüsteemi üleminek eestlaste haldusesse nõudis pea kõikjal pikemat aega. Ajutise valitsuse usaldusmehe asemik Võrus vandeadvokaat Jaan Lõo teatas kohtuministrile, et võttis Võru rahukohtu ruumid, inventari ja dokumentatsiooni üle 24. novembril. Seevastu kreisipealiku juures

\footnotetext{
111 "Saksamaa valitsus Riia lepingu kohta", Tallinna Teataja, nr 71, 23.11.1918.

112 "Kohalik elu", Sakala, nr 4, 22.11.1918.

113 Ibid.

114 “Ülevõtmiseks ei ole enam takistusi”, Postimees: Pärnu väljaanne, nr 200, 23.11.1918.

115 "Pärnu maakonnanõukogu koosoleku protokoll, 25.11.1918”, Eesti Vabariigi sisepoliitika 1918-1920, 246; Pajur, Vunk, Rahvusriigi sünd Pärnumaal, 73.
} 
tegutsenud politseikohtuniku asjaajamine jäigi üle võtmata, sest nii kreisipealik kui ka politseikohtunik põgenesid Võrust niipea, kui sai teatavaks Pihkva langemine enamlaste kätte. ${ }^{116}$ Viljandi-Pärnu rahukogu kinnitusel võeti Viljandis politseikohtuniku asjaajamine üle 26. novembril, kohalik arestimaja 27. novembril, rahukohus ja kinnistusjaoskond 28.-29. novembril ning kohtutäituri aktid 6. detsembril. ${ }^{117}$ Tartu-Võru rahukogu esimees Lui Olesk andis teada, et võttis sakslastelt Tartu ringkonnakohtu, rahukohtu ja kinnistusjaoskonna üle 25. novembril ning et 3. detsembril pidas Tartu-Võru rahukogu oma esimese istungi. ${ }^{118}$

Kõige keerulisemas olukorras olid Lääne-Eesti saared (nn saarte kubermang), millel puudus püsiühendus mandriga. Tallinna ajalehed saartele ei jõudnud, regulaarne laevaliiklus oli katkenud ning mandrile suunduvaid telefoni- ja telegraafiliine kontrollisid Saksa sõjaväelased. Seetõttu jäi teave mujal toimuvast pidevalt hiljaks. Alles 18. novembril sai maanõukogu liige ja endine Saaremaa miilitsülem Juhan Ainson telegrammi, milles teatati tema nimetamisest ajutise valitsuse usaldusmeheks Saaremaal. Samal päeval jõudis Kuressaarde ka Saare-, Hiiu- ja Muhumaa kaitseliidu ülemaks nimetatud kapten Johannes Poopuu, tuues kaasa saarlaste silmis värskeid uudiseid Tallinna sündmustest. Siiski olid needki vananenud, kuna Poopuu lahkus Tallinnast 13. novembril ega olnud samuti uute arengutega kursis.

Ainson asus kohe tegutsema. Esiteks saavutas ta Saksa linnavalitsusega kokkuleppe, mille kohaselt pidi 1917. aastal moodustatud linnavolikogu 19. novembril uuesti kokku astuma. Teiseks saatis ta sõjaväe telefoniliine kasutades kutsed makonnanõukogu liikmetele, paludes neil koguneda 20. novembriks Kuressaarde. Seega näisid asjad esiotsa sujuvat. Kuid 20. novembril kutsus saarte sõjakuberner kindralleitnant William Balck Ainsoni enda juurde ja tegi talle peapesu, kuna makonnanõukogu istungi eel oli heisatud endisele politseihoonele sinimustvalge lipp. Balck oli äärmiselt ärritatud, nimetas seda rahvusvahelise õiguse räigeks rikkumiseks ja nõudis lipu viivitamatut kõrvaldamist, ähvardades vastasel juhul Saksa sõdurite sekkumisega. Ainsoni käsul võetigi lipp maha, mille eest teda omakorda tabas makonnanõukogu liikmete pahameel. Nõukogu kvalifitseeris kindrali ultimatiivse nõude alusetuks, nimetas seda tooreks vägivallaks ja Eesti vabariigi au haavamiseks ning avaldas valju protesti, ent see ei muutnud midagi. Tagajärjetuks jäi ka kontaktivõtt Saksa soldatite

116 RA, ERA.76.1.197, 1. 8-9: Jaan Lõo kohtuministrile, 30.11.1918.

117 RA, ERA.76.1.197, 1. 18: Viljandi-Pärnu rahukogu kohtuministrile, [?].12.1918.

118 RA, ERA.76.1.197, l. 11-16: Lui Olesk kohtuministrile, 03.12.1918. 
nõukoguga, kes kinnitas, et töötab täies üksmeeles kindral Balckiga ega saa tema korraldust muuta.

Olukord keerustus veelgi 21. novembril, mil kindral Balcki käsul teatati Ainsonile ja Poopuule, et Saksamaa ei kavatse ajutist valitsust tunnustada. Ehkki sakslased lubasid Ainsonit mitte takistada, otsustas Ainson pärast säärast Hiiobi sõnumit võimu ülevõtmisest loobuda, volitused maha panna ja nõutada Tallinnast täpsemaid juhtnööre. ${ }^{119}$ Maakonna- ja linnaomavalitsus küll jätkasid tegevust, ent maakonnanõukogu esindajate sõnul edenes töö visalt, kuna "on alalised õerumised Saksa sõjaväe võimudega, mis kõiki meie samme paralüseerib". Ühtlasi kaebas ka maakonnanõukogu olematu side üle mandriga - "ainult juhusliselt [...] on mõned ajalehed saadud" - ning sedastas: "Et meil Tallinnaga ühendus puudub ja meie säälse oludega sugugi tuttavad ei ole ja ajutise valitsuse sammudest sugugi informeeritud ei ole, siis on meie seisukord väga selguseta ja meie ei või tarviliku kindlusega välja astuda. Seepärast palub Saaremaa Maanõukogu, et ajutine valitsus võimalikult ruttu katsuks aurulaeva ühenduse Kuresaare ja Tallinna vahel sisse seada, niisama ka posti, telegraafi ja telefoni ühenduse."120

22. novembril selgus varasema info ekslikkus (valelikkus?). Saaremaa kreisipealik teatas ametlikult, et Saksamaa valitsus tunnustab Eesti iseseisvust, ja palus Ainsonil jätkata maakonna asutuste ülevõtmist. Samal päeval alustas tööd Saaremaa maavalitsus, mille eesotsas seisis 25 -aastane üliõpilane Timotheus Grünthal. Viimanegi põrkus kohe raskustele ja teatas Tallinna: "Saksa võimud annavad asju väga aeglaselt üle ja katsuvad igatipidi viivitada [...] ja on kindel, et ennem nende lõpulikku lahkumist meie korralikult tööd ei saa teha.” Ühtlasi palus Grünthal taas kord juhtnööre. ${ }^{21}$ Päev hiljem koostatud kirjas loetles Grünthal peamisi valupunkte: Saksa sõjavägi asub jätkuvalt Kuressaares, kontrollib sideühendusi ja korraldab oksjoneid, et sõjaväevara rahaks teha; asutuste üleandmine küll jätkub, kuid sakslased tõrguvad sageli, nt ei taha loovutada kreisipealiku kassat, väites selle olevat Saksa riigi raha; mitme asutuse dokumentatsioon on täielikult hävinenud, mh olla maakonnavalitsuse arhiiv talvel ahjukütteks läinud; suurt muret valmistab toitlusküsimus, kuna tänavune viljasaak jättis soovida ja väljast pole lisa toodud; ei piisa raha hädavajalike väljaminekute

119 RA, ERA.31.1.3, 1. 46-49: Juhan Ainson Ajutisele valitsusele, 21.11.1918.

120 RA, ERA.31.1.3, 1. 51: Saaremaa maakonnanõukogu ja maakonnavalitsus Ajutisele valitsusele, 21.11.1918.

121 RA, ERA.31.1.3, l. 52: Timotheus Grünthal Ajutisele valitsusele, 22.11.1918. 
katmiseks, aga uusi makse kehtestada ei ole võimalik, sest sakslased on aasta jooksul rahva paljaks riisunud. ${ }^{122}$

Tasapisi näisid olud siiski normaliseeruvat. 25. novembril tulid Kuressaares kokku Saaremaa vallavanemad ning rõómustava tõsiasjana selgus, et "on kohtadel ajutise valitsuse korraldused üleüldiselt elusse viidud. Meeleolu on kohtadel rahulik, kokkupõrkamisi Saksa sõjaväe ja rahva vahel pole ette tulnud. Ajutisele Valitsusele avaldab rahvas igalpool usaldust. Valitsusevastalist kihutustööd pole tänini märgatud. Ametieestseisjad on omad kohustused vallavalitsustele üle annud". Maksude osas lepiti kokku, et Saksa võimude poolt määratud maksud tuleb sisse nõuda. Toitlusküsimus leiti küll "kaunis kriitiline" olevat - 18-st vallast ei tulevat pooled omaenda tagavaradega välja ning ainult neli valda suudaksid teisi abistada -, ent arvati siiski optimistlikult, "et talve ehk kuidagi üle saame". Maakonnakassa oli lõpuks üle võetud, ehkki selles leidus vaid 42 ooo marka. Samuti oli alustatud kohtute korraldamist ning püsiva postiühenduse taastamine Kuivastu ja Virtsu vahel näis edenevat. ${ }^{123}$ Seega alustasid saarlased küll hilinemisega, ent tegid mahajäämuse Mandri-Eestist peagi tasa.

Tartlased, kes olid kavandanud suurt protestimeeleavaldust, jahtusid pärast "Riia rahu" sõlmimist maha. 20. novembri Postimees kuulutas: "Nõudmiste täitmist on kindlasti lubatud. Meeleavaldus jääb täna ära." Seda otsust ei muutnud isegi tõsiasi, et samale hommikule kavandatud linnavalitsuse üleandmine lükkus edasi järgmisele päevale ning raekoja võtmete asemel ulatati Jaan Kriisale hoopis telegramm. Selles teatas Tartu linnapealiku asetäitja, et on saanud Winnigilt korralduse anda linnavalitsus eestlastele üle 21. novembril, aga "enne seda mitte milgi tingimisel linna valitsemist käest ära anda". ${ }^{124}$ Venitamine jätkus ka järgmisel hommikul, mil raekotta jõudnud Kriisale öeldi, et üleandmine ei saa alata enne õhtut ja seni ei panda raekojale ka eesti lippu. Lipuheiskamisele kogunenud linnarahvas läks pettunult laiali. ${ }^{125}$

Kuid igale venitamisele tuleb lõpp ja järgmistel päevadel andis Postimees teada järjest uutest edusammudest. Alanud protsessi ulatust ja keerukust väljendavad järgnevalt toodud väljavõtted ajalehest.

122 RA, ERA.31.1.3, 1. 53: Timotheus Grünthal Ajutisele valitsusele, 23.11.1918.

123 RA, ERA.31.1.3, 1. 54: Timotheus Grünthal Ajutisele valitsusele, 26.11.1918.

124 "Kohalikud teated", Postimees, nr 220, 20.11.1918.

125 “Valitsuse asutuste üleandmine algab täna", Postimees nr 221, 21.11.1918. 
22. novembril:

- [eile] kell 5 p.l. ilmus linnapää Kriisa ühes linnavalitsusega [...] raekotta, kus vana linnavalitsus koos oli. Üleandmine algas kohe ja kestis täna hommikupoolel edasi.

- Tartu politseivalitsus võeti eile miilitsaülema K. Einbundi poolt üle. - eile pääle lõunat k. 4 algas Tartu postkontori ülevõtmine.

- linna toitlusameti ülevõtmiseks on J. Raudsepp valitud, kes sellega täna pääle algas.

- maakonna toitlusamet ja kroonumaade valitsus anti täna kl. 10 hom. Eesti Ajutise Valitsuse volinikkude kätte.

- linna haigemajade üleandmine sünnib täna.

- elektrijaama ja gaasivabriku valitsus anti täna hommikul meie demokraatlise linnavalitsuse asemikkude kätte. ${ }^{126}$

23. novembril:

- linnavalitsuse ülevõtmine kestab ikka edasi. [...] Eile võeti üle maksu- ja teateamet, linna koolide jaoskond, küttematerjali ja sõjakahjude kindlaksmääramise osakond ja muud linnavalitsuse harud. Takistusi sünnitab rahaasjade üleandmine.

- maakonnavalitsuse ülevõtmine algas [...] eile k. 4.55 min. pääle lõunat. ${ }^{127}$

25. novembril:

- linna- ja kreisipäälikult on nüüd kõik asutused üle võetud. Asjas on ainult veel see takistus, et kreisipäälik kreisi ameti kassaraamatuid üle ei taha anda; niisama [...] ka linnapäälik.

- vangimaja ülevõtmine sündis laupäeval [...] hulk isikuid, kes senini okupatsioonivõimude määruste põhjal kinni peeti, vabaks lasti, välja arvatud kurjategijad. ${ }^{128}$

26. novembril:

- Tartu rentei on üle võetud ja jätkab oma endist tegevust.

- Tartu jaama komissar A. Luiga on oma tegevusesse astunud.

- linnavalitsuse asjaajamise ülevõtmine seniselt Saksa linnavalitsuselt eile 25. skp. lõppes. [...] Eesti lipp pandi selle järele kui vana linnavalitsus asjaajamise üleandmise täielikult oli lõpetanud, eile lõuna ajal raekojale üles. ${ }^{129}$

126 "Kohalikud teated", Postimees, nr 222, 22.11.1918.

127 “Kohalikud teated", Postimees, nr 223, 23.11.1918.

128 "Kohalikud teated", Postimees, nr 224, 25.11.1918.

129 "Kohalikud teated", Postimees, nr 225, 26.11.1918. 
Vastavalt Riia lepingule kuulus üleandmisele ka Tartu ülikool, millest oli 15. septembril saanud ühendatud Balti hertsogiriigi ülikool (Landesuniversität). Kuid olukorra muutumise tõttu soikus õppetöö juba novembris ning 27. novembril anti õppejõudude koosolekul teada saksa ülikooli tegevuse lõpetamisest. ${ }^{130}$ Landesuniversität'i sisulise juhi, Berliini ülikooli õigusteaduse eradotsendi kapten Hans Helfritzi jaoks kujunes nüüd peamiseks küsimuseks - kellele anda üle ülikool. Kuna tegemist oli kolme endise kubermangu jaoks asutatud kõrgkooliga, ei pidanud Helfritz selle loovutamist Eesti vabariigile sobilikuks. Seetõttu tegi Helfritz Saksa väejuhatusele ettepaneku anda ülikool ajutiselt üle professor Aleksander Paldrockile, keda ta iseloomustas kui erakordselt saksasõbralikku isikut. ${ }^{131} 30$. novembril teavitas Helfritz oma otsusest ka ajutise valitsuse Lõuna-Eesti peavolinikku Heinrich Luhti. Viimane deklareeris vastuseks, et Riias sõlmitud lepingu kohaselt tuleb ülikool anda üle Eesti valitsusele, kes määrab ühtlasi ametisse ülikooli kuraatori. ${ }^{132}$

Ülikooli üleandmine tuli eestlaste jaoks sedavõrd ootamatult, et Luht oli sunnitud ise Peeter Põllu ülikooli ajutiseks kuraatoriks nimetama (ajutine valitsus kinnitas vastava ettepaneku päev hiljem). ${ }^{133}$ Pühapäeval, 1. detsembril, võtsid Luht ja Põld Tartu ülikooli 8. armee staabi juures tegutsenud ülikoolivalitsuselt (Universitätsverwaltung beim Armeeoberkommando 8) üle. Lühikesse akti märgiti, et ülikoolil on õigus nõuda Tallinna ja Tartu linnavalitsustelt sisse varem lubatud toetusrahad (vastavalt 25000 ja 100000 marka), et praegune üleandmine ei lahenda ette ära küsimusi, mis võivad tekkida edaspidi asjaosaliste riikide vahel, ning et telefoni sisseseaded kuuluvad jätkuvalt Saksa sõjaväele. Ühtlasi pandi kirja sakslaste soov jätta ülikooli ametnikud nende kohtadele. ${ }^{134}$

4. detsembril võttis Põld seniselt rektorilt Karl Dehiolt vastu asjaajamisaktid ja ülikooli pitsatid. ${ }^{135}$ Samuti määrati ametisse ülikooli asutuste ja nende varade ülevõtjad ning moodustati komisjon ülikooli varade olukorra

130 Tartu ülikooli ajalugu, III: 1918-1982 (Tallinn: Eesti Raamat, 1982), 23-27; Sirje Tamul, "Landesuniversität Tartus 1918. aastal”, Universitas Tartuensis 1632-2007 (Tartu: Tartu ülikooli kirjastus, 2007), 261-269; Reinhold Zilch, "Dokumente ja materjale Tartu saksa ülikooli kohta aastast 1918", Tuna, 1 (2010), 70-89; Artur Luha, "Okupatsiooniaegne Saksa ülikool ja Tartu eesti üliõpilaskond”, Üliõpilasleht, 6 (1932), 144-150.

131 Reinhold Zilch, "Dokumente ja materjale Tartu saksa ülikooli kohta aastast 1918", Tuna, 1 (2010), 87.

132 RA, ERA.31.1.4, 1. 2: Heinrich Luht Ajutisele valitsusele, 30.11.1918.

133 Ibid.; RA, ERA.31.1.8, 1. 47-48: Ajutise valitsuse koosoleku protokoll, 02.12.1918.

134 RA, ERA.31.1.3, 1. 92: [Tartu ülikooli üleandmisakt], o1.12.1918; "Akt”, Riigi Teataja, nr 10, 1918, 7.

135 Tartu ülikooli ajalugu, III, 27. 
väljaselgitamiseks. Komisjoni ja ülevõtjate töö tulemusena võis Peeter Põld teatada 18. detsembril ajutisele valitsusele: "1. dets. võeti Tartu Ülikooli Valitsus ametlikult [...] üle. [...] Samal päeva sõitsid kõik väljamaalt pärit olevad professorid ja ametnikud ära ühes Saksa ülikooli asjaajamise paberitega ja arveraamatutega, järele jättes Eesti Valitsusele tühja kassa [...]." Positiivset märkimist pälvis asjaolu, et sakslased polnud lasknud ülikooli varasid laiali tassida, vaid üritasid neid säilitada ja osalt isegi täiendada, ning maksid enne lahkumist välja ametnike palgad kuni aasta lõpuni. Siiski jäi olukord keeruliseks ja näiteks ülikooli hoonete kütmine ähvardas kujuneda ületamatuks probleemiks. Kuraator resümeeris: esialgu on võimalik töös hoida vaid hädatarvilikud kliinikud (haavakliinik, närvikliinik, naistekliiniku sünnitusosakond ja võib-olla ka silmakliinik) ning observatoorium (tähetorn ja meteoroloogia jaam). Enamik ametnikke tuli alates 31. detsembrist vabastada. ${ }^{136}$

Kui suurem osa Lõuna-Eestist võeti sakslastelt üle 22.-26. novembril, siis üks Eesti tulevastest maakondadest - Petserimaa - läks sakslaste haldusest otse vene enamlaste kätte. Selle piirkonna staatus oligi kõige ebaselgem, kuna varasem Liivimaa ja Pihkva kubermangude vaheline administratiivjoon oli jätnud Setumaa Pihkva poolele. 1917. aastal oli küll taotletud Setumaa liitmist Eestiga, kuid siduvate otsusteni ei jõutud. Saksa okupatsiooni päevil allutati Pihkva kubermangu loodeosa Lõuna-Eestit hallanud 6o. kindralkomandole. ${ }^{137}$

Saksamaa kokkuvarisemisel peeti Tallinnas nähtavasti loomulikuks, et Brest-Litovski rahulepingu järgselt kujunenud demarkatsioonijoon jääb püsima. Igatahes otsustas ajutine valitsus 17. novembril nõuda August Winnigilt koos ülejäänud Lõuna-Eestiga ka Petserimaa üleandmist valitsuse volinikele. ${ }^{138}$ Selle seisukohaga haakus 21. novembril peaministrile läkitatud setumaalaste kiri, milles nõuti Setumaa ühendamist Eestiga, idapiiri sulgemist, toiduainete väljaveo tõkestamist ja venemeelse kihutustöö lõpetamist. Selleks soovitati saata Setumaale Eesti väeüksused ja nimetada kohapeale valitsuse esindaja. Sõjaväge ajutisel valitsusel veel ei olnud, kuid valitsuse usaldusmees määrati Petserisse juba 20. novembril. Selles ametisse nimetati ligi veerandsada aastat preestri, koolimehe ja seltsitegelasena setusid äratanud Karp Ustavi poeg Boris Ustav. ${ }^{139}$

\footnotetext{
136 RA, ERA.31.1.3, 1. 91: Peeter Põld Ajutisele valitsusele, 18.12.1918.

137 Kalle Lõuna, Petserimaa: Petserimaa integreerimine Eesti Vabariiki 1920-1940 (Tallinn: Eesti Entsüklopeediakirjastus, 2003), 21, 24-25.

138 RA, ERA.31.1.8, 1. 13: Ajutise valitsuse koosoleku protokoll, 17.11.1918.

139 Lõuna, Petserimaa, 25-26; RA, ERA.31.1.8, 1. 26: Ajutise valitsuse koosoleku protokoll, 20.11.1918.
} 
Valitsuse peavolinikud Lõuna-Eestis Karl Parts ja Heinrich Luht saatsid ka oma esindaja, "et Petserimaal asuvaid ametiasutusi ja riigivarandusi Saksa sõjaväelise okupatsioni võimude käest Eesti Ajutise Valitsuse kätte ülevõtta”. Too nimetuks jäänud volimees jõudis 27. novembri hommikul rongiga Võrru, kus kohtus Petserist põgenenud kohalike tegelastega. Viimased kinnitasid ühest suust, et nemad tagasi ei lähe, sest Saksa sõjavägi ei taga mingit kaitset ja kohalikud enamlased suhtuvad neisse vaenulikult. Pealegi polevat Petseris enam midagi üle võtta, kuna Saksa kreisipealik, toitlusohvitserid jt ametnikud on "ühes kõigi maakonna ja toitluse komiteede kassade ja dokumentidega" Riiga põgenenud. Vaid üks ladu olevat maha jäänud. Petserlaste kinnitusel polevat valitsuse usaldusmeest Boris Ustavit Petseris nähtud.

Samas aruandes iseloomustati põgusalt ka Võrus valitsenud olusid: kuigi punaväed jäid pärast Pihkva hõivamist Irboska alla peatuma, käitusid Petseri poolt saabunud Saksa sõdurid paaniliselt ega täitnud väejuhatuse käske, Tartust Petserisse käsutatud abivägi aga keeldus Valgast edasi sõitmast; Võrus tegelesid Saksa sõjaväelased eestlaste relvitustamisega, võttes ära ajutise valitsuse poolt Tallinnast saadetud relvad; samal ajal pakkisid Saksa sõjaväeasutused Võrus oma kraami kokku ja valmistusid lahkumiseks; Võru eesti tegelaste meeleolu iseloomustati seevastu lootusrikkana ja kaitseliitlaste tegevust elavana. ${ }^{140}$

\section{Lõpetuseks}

Saksa okupatsiooni varisemine sai alguse Tallinnast, kus ajaliselt langesid kokku kolm mõjutegurit: esiteks, novembrirevolutsioon Saksamaal viis keisri kukutamise ja vabariigi väljakuulutamiseni; teiseks, selle tulemusena vallandunud revolutsiooniline liikumine Tallinna garnisonis; ning kolmandaks, toitluskriisi tagajärjel tekkinud rahutused eestlaste seas. Toimuvast segadusse sattunud Saksa sõjaväevõimud andsid loa maanõukogu kokku kutsumiseks.

Kuna maanõunike koondamine nõudis aega, tõlgendasid eestlased järeleandmisi omatahtsi ja taastasid 11. novembrist ajutise valitsuse tegevuse. Ühtlasi käivitati Tallinnas saladuskatte all loodud kaitseliit, asendati Saksa politsei Eesti miilitsaga ning asuti lahendama toitlusprobleemi. Saksa sõjaväevõimud olid sunnitud ajutist valitsust tunnustama.

13. novembril algas Saksa haldusasutuste ülevõtmine Tallinnas ning ajutise valitsuse võim laienes maakondadesse, kuhu määrati valitsuse

$\overline{140}$ RA, ERA.31.1.3, 1. 87-88: Aruanne Kaarel Partsile ja Heinrich Luhtile, 30.11.1918. 
volinikud (usaldusmehed). Põhja-Eestis teostus Saksa tsiviilametnike kõrvaletõrjumine, kohalike omavalitsuste taastamine ning korrakaitse- ja kohtuasutuste ülevõtmine loetud päevade jooksul ja suuremate tõrgeteta.

Lõuna-Eestis ja Lääne-Eesti saartel keeldusid aga sakslased võimu eestlastele loovutamast ning rakendasid Tartus ilmunud eesti ajalehtede suhtes repressiivseid meetmeid, mis omakorda ähvardasid tuua kaasa kokkupõrkeid. Olukorra lahendamiseks astusid ajutise valitsuse esindajad Riias läbirääkimistesse Saksa riigi peavolinikuga Baltimaades August Winnigiga. Kõneluste tulemusena valminud kokkulepe, mida võib pidada Eesti vabariigi esimeseks välislepinguks, kohustas sakslasi 21. novembril võimu lõplikult eestlastele andma. Vaatamata kohati jätkunud venitamispüüetele saigi see novembri lõpupäevil teoks.

\section{AвSTRACT: The takeover of Estonia from the German occupying authorities in November of 1918}

Although the independent Republic of Estonia was declared on 24 February 1918, the German occupation that followed prevented the actual establishment of statehood. The chance for this did not come until November of that same year, when Germany's defeats on the Western Front and the November Revolution that broke out as the expression of worsening discontent brought an end to the First World War and German domination in Eastern Europe.

The policy of the occupying authorities in Estonia was aimed at neutralising society, and in this way the Germans succeeded in preventing active resistance. Nevertheless, news of Germany's military setbacks also reached Estonia and aroused some measure of hope for a better future. The cautious rebirth of political activity was noticeable in October of 1918 . The way subsequent events took shape was nevertheless a surprise for both the German authorities and Estonian politicians.

The breakthrough started with spontaneous riots that broke out in Tallinn on 7 November arising from food shortages. These rapidly snowballed into a city-wide strike. Political demands emerged alongside demands for improving the supply of food: demands for the withdrawal of German troops from Estonia and for transferring power to the institutions of local 
government that had been democratically elected in 1917. News of the November Revolution in Germany reached Tallinn at the same time, triggering unrest in the city garrison. Lieutenant General Adolf von Seckendorff, commander of the 68th Army Corps and the highest ranking local administrator, was forced to seek support from Estonian politicians. As a result of these events, the Estonian Provisional Government convened on 11 November and this date can be considered the starting point of the building of the independent Estonian state.

The Provisional Government first had to take the reins of power into its own hands. This was accomplished quickly and smoothly in Tallinn and Northern Estonia, which were in the administrative area of the 68th Army Corps. General Seckendorff recognised the Estonian Provisional Government on 13 November. At the same time, Estonians took over the Provincial Government of Estonia, the Food Office, the judicial and prison systems, post offices, ports, etc. The Provisional Government appointed its proxies (deputies) in the counties and ordered the reconvening of the local county, municipal and rural municipal governments. The municipal police force (militia) that had been formed in 1917 was restored, to which the newly formed voluntary armed organisation known as the Kaitseliit [Defence League] was added. The representative popular assembly - the Maanõukogu - reconvened after an interval of a year on 20 November, and as fate would have it, Prime Minister Konstantin Päts arrived in Tallinn on the same day after being released from a camp for interned persons and took up his position at the head of the government.

Yet in Southern Estonia in the territory occupied by the 6oth Army Corps, the Germans refused to relinquish power, referring to the fact that they had not received orders to this effect. A particularly serious conflict appeared to be brewing in Tartu, where Estonians were preparing a large demonstration for pushing through their demands. The Provisional Government sent representatives to Riga, where August Winnig, Germany's Minister Plenipotentiary to the Baltic Provinces, resided, to resolve the situation that had developed. According to the agreements concluded with him, the Germans committed themselves to relinquishing power to Estonians throughout Estonian territory starting on 21 November. Even though further attempts to delay this were made in some places, from that point on, power in Southern Estonia as well was transferred into the hands of the Provisional Government's deputies and the local governments. This process proceeded with probably the greatest difficulty on the Western Estonian islands, where a drought of information prevailed since they were 
cut off from the mainland. Only the future Petseri County (Setomaa) was not taken over and shortly thereafter was subjected to the control of the armed forces of Soviet Russia.

KeYwords: History of Estonia, First World War, German occupation, November Revolution, Estonia’s Provisional Government, Estonia’s Maanõukogu (Diet)

Ago Pajur (b. 1962) is Associate Professor at the Institute of History and Archaeology, University of Tartu.*

* Correspondence: Institute of History and Archaeology, University of Tartu, Jakobi 2, 51005, Estonia. E-mail: ago.pajur@ut.ee 